\title{
Statistical Assessment of Damage to Churches Affected by the 2010- 2011 Canterbury (New Zealand) Earthquake Sequence
}

\author{
The Canterbury Region of New Zealand experienced an extensive earthquake \\ sequence during 2010-2011, with two particularly severe events being on 4 \\ September 2010 and 22 February 2011. The presented work entails a statistical \\ analysis of the data collected for 112 churches in the affected region, including in \\ situ damage observed by the authors and the structural assessment classification \\ assigned by local authorities. The seismic performance of these churches is \\ discussed and compared with both the structural classifications used in Italy, \\ where a specific survey form for churches is used, and with the building damage \\ classifications assigned by the local authorities.
}

Keywords: church; seismic performance; post-earthquake assessment; collapse mechanism; damage assessment form

\section{Introduction}

It is often stated that the history of a country can be told by its heritage buildings. These buildings have an invaluable cultural significance but because of their architectural characteristics, construction materials and deterioration resulting from ageing, these heritage buildings are often highly vulnerable to extreme hazard events such as earthquakes. The seismic vulnerability of heritage buildings is much relevant for New Zealand (NZ), as the country’s indigenous Maori population did not employ durable construction materials [Russell and Ingham, 2010] and the country was one of the last lands to be colonised by Europeans. Hence the country's identity is represented by a comparatively small heritage building stock dating from 1833, emphasising the need for seismic retrofit implementation to ensure that these heritage buildings can be retained for use by future generations.

When a region is struck by an earthquake, a specific procedure is triggered by the local authorities who have two different types of objectives when undertaking post- 
earthquake emergency assessment of buildings [Anagnostopoulos and Moretti, 2006]. The primary objectives are the protection of human life and property, while the secondary objectives are related to minimising the number of people made homeless by rapidly assessing buildings as safe or unsafe, evacuating dangerous areas, and creating shelter sites. In addition to data collection to inform the above objectives, data are also sought for purposes such as: (i) for authorities to develop disaster mitigation policies and allocate funds based on reliable estimates; (ii) for identification of the causes of damage, so that rehabilitation plans can take these hazards into account; (iii) for research, so that standards and construction practices can be re-evaluated, along with the development of supplementary resources such as seismic hazard maps. The methodology used for the seismic safety evaluation of buildings needs to be clear and straightforward, so that flaws can be limited to a minimum and reliable data can be retrieved. This need for clarity is a core issue as a variety of activities will be based on this information, such as building demolition and provisional securing interventions in the short term and the publishing of standard updates in the long term. Strong aftershocks are common and for that reason building assessments must be undertaken as quickly and as safely as possible due to the risk of collapse of damaged structures.

Because the complexity of heritage buildings represents a challenge to rapid and accurate post-earthquake damage assessment, Italian authorities developed a specific survey form for churches [Civil Protection Department, 2006]. Churches usually have a high seismic vulnerability due to their structural arrangement and geometric proportions, material composition, and potentially deteriorated condition due to their age. The systematic documentation of damage sustained by churches in the Friuli earthquake [Doglioni et al., 1994] led to definition of the macroelement concept, where the collapse mechanisms of church are distinguished based upon the failure of 
individual structural components (such as facades, side chapels, bell towers and presbyteries) that are assumed to effectively behave autonomously. According to [Civil Protection Department, 2006], inspectors are expected to identify possible collapse mechanisms from a list on the form and then grade the activated mechanisms within a scale [Grunthal et al., 1998]: 1-Negligible to slight damage; 2-Moderate damage; 3Substantial to heavy damage; 4-Very heavy damage; 5-Destruction. The first version of the form had 18 possible collapse mechanisms [Angeletti et al., 1997] and was used to assess almost 3000 churches in Umbria-Marché, Italy, after the earthquake of 26 September 1997 [Lagomarsino and Podestà, 2004] and in Molise, Italy, after the earthquake on 31 October 2002 [Lagomarsino and Podestà, 2004a]. The form was also applied in the Azores, Portugal, after the earthquake on 9 July 1998 [Guerreiro et al., 2000]. In both cases, the macroelement approach was considered effective. Based on this experience, the current version of the form [Civil Protection Department, 2006] has 28 possible collapse mechanisms and was used in L'Aquila, Italy, for the assessment of churches damaged by the earthquake on 9 April 2009 [Podestà et al., 2010]

The Canterbury Region in the South Island of NZ underwent two severe earthquakes on 4 September 2010 and 22 February 2011 [Bradley and Cubrinovski, 2011; Gledhill et al., 2010]. Chronologically separated by only five months, and with epicentres located close to urban areas, the region suffered considerable human and material losses [NZ Police, 2011; NZ Treasury, 2011]. In additional to building damage, much of the civil infrastructure sustained damaged due to the geotechnical phenomena of liquefaction and lateral spreading [Allen et al., 2010; Cubrinovski et al., 2011]. The Central Business District (CBD) of Christchurch, the largest city of NZ's South Island and the nation's oldest and second largest city, was partially destroyed in February 2011 and had to be evacuated. A large number of heritage buildings, mostly constructed using 
unreinforced clay brick masonry, partially collapsed or were damaged beyond repair [Dizhur et al., 2011].

In order to study the behaviour of the masonry and heritage buildings in the region affected by the Canterbury sequence, an international team of post-graduate students was deployed in Christchurch soon after the 22 February 2011 earthquake with coordination provided by the University of Auckland and funding provided by the NZ Natural Hazards Research Platform. Statistical analysis of the damage data gathered for churches in the region is presented here, followed by safety evaluation data collected by NZ authorities, as well as data on the damage classification registered for each church by the NZ authorities. The above mentioned Italian survey form was used for each church inspected, and the results are compared with those registered by the authorities. Almost all churches of the Canterbury region built before 1938 were assessed [Hamilton and Hamilton, 2008], leading to a total of 112 church buildings being contained within the dataset (see Figure 1). The exceptions were churches that were already demolished and churches that were damaged to such an extent that it was unsafe to perform the assessment.

\section{Past seismic activity in the Canterbury Region}

Christchurch is the second largest city in NZ, with 338.748 inhabitants [Statistics New Zealand, 2006], and is located on the east coast of NZ's South Island. The city has been struck by eleven medium sized earthquakes since European settlement [NZ Government, 2011], but only three earthquakes have resulted in reported damage to buildings. The earthquake that occurred on 5 June 1869 had an intensity of MM 7 in Christchurch City centre and of MM 5 in the surrounding boroughs, and caused damage to chimneys, government buildings, churches and homes [Christchurch City Libraries, 2006], while for the earthquake that occurred in 1881 the only reported damage was to 
the spire of the Christchurch Cathedral [GeoNet, 2011b]. The earthquake that occurred in 1888 had an estimated intensity of MM 9 and an epicentre located $100 \mathrm{~km}$ north of the city [GeoNet, 2011b] and caused only minor damage to buildings [PapersPast, 2010].

Because Christchurch is located near the coast and at a significant distance from the main Alpine Fault that divides the South Island longitudinally, the NZ Loadings Standard [NZS 1170.5, 2004] considers the city to be a moderate hazard area.

\section{September 2010}

At 4.35 am on 4 September 2010 a magnitude $M_{w} 7.1$ earthquake struck the Canterbury region. The epicentre was located near Greendale, $40 \mathrm{~km}$ west of Christchurch (see Figure 2), at a depth of about $10 \mathrm{~km}$. The earthquake produced a ground-surface fault rupture with a length of nearly $30 \mathrm{~km}$ (see Figure 3) and during the ground motion the measured Peak Ground Accelerations (PGAs) reached 0.82g for the horizontal component and 1.26g for the vertical component [Allen et al., 2010]. There were no fatalities and only two serious injuries, which was partly due to the timing of the earthquake in the early hours of a Saturday. The seismic activity was particularly interesting from a geotechnical perspective because of the surface rupture [Allen et al., 2010]. Liquefaction and lateral spreading can be considered fairly common phenomena in earthquakes, and are generally registered following strong ground motions [Maugeri et al., 2011] but in the Darfield earthquake these phenomena were the main cause of damage to buried infrastructure and bridge abutments [Allen et al., 2010], due to their extent. 


\section{February 2011}

Between 4 September 2010 and 22 February 2011 almost 1500 aftershocks having a magnitude of $\mathrm{M}_{\mathrm{w}} 3.0$ or greater were recorded [GeoNet, 2011a], but none was as severe as the event that occurred at 12:51 pm on 22 February 2011. With a magnitude of $\mathrm{M}_{\mathrm{w}} 6.3$ and an epicentre located only $10 \mathrm{~km}$ south-east of Christchurch at a depth of $5 \mathrm{~km}$, this earthquake was felt throughout the entire Canterbury region (see Figure 4). The infrastructure of the city was again heavily damaged, and the Christchurch CBD was partially destroyed. More than 180 people lost their lives and a similar number were severely injured [NZ Police, 2011]. This same area was considered unsafe by the Ministry of Civil Defence and Emergency Management and was cordoned to prevent public access.

The epicentre of the 22 February 2011 earthquake was located beneath the hills to the south-east of the city and caused boulders to become dislodged and roll downhill (see Figure 5 (a)), resulting in damage to houses and cars and injuring people. The cliffs along the coast were also affected by the earthquake, either partially collapsing or becoming unstable, and several houses located at both the top and the bottom of these cliffs were damaged or had to be evacuated permanently. The previous geotechnical problems happened once more, with all the suburbs along the Avon River being subjected to liquefaction (see Figure 5 (b)) and lateral spreading (see Figure 5 (c)). The relapse of these phenomena in certain areas led the Earthquake Commission (EQC) and the newly assembled Canterbury Earthquake Recovery Authority (CERA) to classify the City Centre and the surrounding suburbs as green, yellow or red residential zones [Canterbury Earthquake Recovery Authority, 2011] (see Figure 5 (d)).

After 22 February the aftershocks continued and on 13 June 2011 two large aftershocks occurred, the first having a magnitude of $\mathrm{M}_{\mathrm{w}} 5.7$ and the second having a 
magnitude of $\mathrm{M}_{\mathrm{w}}$ 6.3, with epicentres located near Christchurch City. More buildings were damaged in the Christchurch CBD during these 13 June 2011 aftershocks.

\section{Safety Evaluations}

New Zealand legislation requires that immediately after the declaration of a state of emergency [New Zealand Legislation, 2002], a building safety evaluation process is activated. This procedure was followed in Christchurch City and surrounding districts after the earthquakes in September 2010 and February 2011. The process overview and guidelines are reported in [New Zealand Society for Earthquake Engineering, 2009] and were based on North American procedures developed by the Applied Technology Council [Applied Technology Council (ATC), 1989; Applied Technology Council (ATC), 1995].

An immediate overall damage survey was performed by the Civil Defence and Territorial Authorities within hours of each event, with the objective of defining priority intervention areas and the human and technical resources required. Two levels of rapid assessments were next undertaken. Level 1 assessments were performed by structural and civil engineers, as well as by architects and other personnel from the building industry, with all buildings being assessed except for critical facilities and multi-storey buildings. The survey form requires identification of the structural system, occupancy class and any structural damage that was visible by external observation. At the completion of the assessment the inspector assigned a placard (see Figure 6) to the building: green if there were no restrictions to use of the building; yellow if there were safety concerns, restricting use of the building to shorts periods of time for essential business; and red if the building was clearly unsafe and therefore re-entry of the building was prohibited. Level 2 assessments were more thorough and therefore were only undertaken by experienced structural and geotechnical engineers, and were 
completed for critical facilities and multi-storey buildings, as well as for all buildings that received yellow or red placards during the Level 1 assessments. For a Level 2 inspection an assessment was required of overall, structural, non-structural and geotechnical hazards.

The placards posted were valid during the state of emergency, superseding the Dangerous Buildings Notice posted under the Building Management Act 2004 [New Zealand Legislation, 2004]. The engineers that performed these assessments were mainly volunteers. After the first earthquake on 4 September 2010 nearly 100 engineers teamed up with NZ Fire Service Urban Search and Rescue (USAR) members, and the inspections started 12 hours after the shock [Wood et al., 2010].

\section{Damage inspection in Churches}

New Zealand became a colony of the British Empire in 1840. After this date the immigrant population increased exponentially, as did the demand for residential and community buildings [Russell and Ingham, 2010]. The first churches during this period were built mainly in timber because of the simplicity of construction, the wide availability of the material and a fast construction time. With growing prosperity stone and clay brick masonry started being used for the construction of important and public buildings, including churches, such that these three materials were the most common to be used for the construction of older NZ churches from the first quarter of the $20^{\text {th }}$ century (see Figure 7). It is also possible to find a few churches built with reinforced concrete as well as churches constructed with a combination of the above mentioned materials.

As for all buildings affected by the Canterbury earthquakes, churches were assessed using Level 1 and, if necessary, Level 2 inspections. As stated above, almost all churches of the Canterbury region built before 1938 were assessed [Hamilton and 
Hamilton, 2008], leading to a total number of 112 church buildings contained within the dataset. This survey included the recording of the placard that was assigned to each church during the required safety evaluation and a visual inspection (exterior and interior when possible and safe) with photographic documentation of the damage (see Figure 8). Following this survey, the Italian survey form for damage in cultural heritage - churches [Civil Protection Department, 2006] was completed.

\section{Italian survey form for churches}

A specific survey form for churches was used for the first time in Italy in 1997, after the Umbria-Marche earthquake. The development of this form began in 1983 by the newly created GNDT (National Group for the Defence from Earthquakes), as a subdivision of the Italian Civil Protection and the SSN (National Seismic Survey), and was later revised by the Università degli Studi di Genova. Without guidelines and a specific inspection procedure, decisions based on human judgement can be ambiguous and different teams assessing the structural safety of buildings can provide diverse results. The use of a form mitigates this difficulty, giving more confidence and credibility to decisions related to interventions on the damaged structures. The objectives of the form are to: (i) allow or restrain full use of a building, or just a part of it; (ii) prioritize interventions on churches, including temporary measures; (iii) estimate a possible cost for the required interventions [Lagomarsino, 2012]. In the present work, only two parts of the form were used: the Fitness For Use classification (FFU), and the method of collapse mechanism identification and classification, along with computation of the damage index $\left(i_{d}\right)$.

In the FFU classification a church receives one of six classifications (see Figure 9) which defines its general use. Depending on the classification, the inspector may consider that the church can still be used (Safe option), may have a limited use or no use 
at all (Unsafe; Unsafe due to External Causes; Partially Safe), impose and specify temporary safety measures (Safe with precautions), or consider that a more thorough inspection needs to be performed (Temporarily Unsafe). This classification scheme is similar to the three colour placard assignment undertaken by Urban Search and Rescue (USAR) and the teams of volunteer engineers following the Christchurch earthquakes, but is a slightly more complex process.

The hierarchy of the interventions on the assessed buildings is achieved by computing a Damage Index $i_{d}$, based on the concept of macroelements [Doglioni et al., 1994]. These macroelements are subdivisions of the church based on architectural elements (such as facade, lateral walls, chapel, bell tower) which have an almost independent seismic behaviour at collapse, therefore simplifying the complex structure of most churches into several smaller and simpler elements. The concept is based on experience acquired from past earthquakes, and was later revised and applied to the inspection forms [Angeletti et al., 1997; Giuffrè, 1999; Lagomarsino and Podestà, 2004] used by the Italian Civil Protection. The purpose of the current form [Civil Protection Department, 2006] is to assist building inspectors to generate more homogeneous evaluation and results by helping them to identify the macroelements that were activated during the earthquake from a list of 28 possibilities (see Figure 10) and to assess the amount of damage that each macroelement sustained by classifying the damage from 0 to 5 following the EMS-98 proposal [Grunthal et al., 1998]. Afterwards, a Damage Index $i_{d}$ is computed using the equation:

$$
i_{d}=\frac{d}{5 n}
$$

where $d$ is the sum of all scores of damage for all the activated macroelements associated with a particular building and $n$ is the number of possible macroelements for 
the particular church being surveyed, including the non-activated macroelements.

The objectives of the Italian survey form extend beyond the macroelement identification and computation of the damage index. By filling in all the other sections of the form, it is possible to register information about the church itself, general damage and seismic vulnerability, and to assist decisions about the viability and detailing of temporary propping and other safety measures [Costa, 2009; Grimaz, 2011]. It is also possible to estimate the cost of the required interventions by an economic loss model, based on the damage level in each macroelement [Lagomarsino and Podestà, 2004a].

\section{Statistical Analysis}

The work presented herein was undertaken between May and July 2011, after the two major earthquake events of 4 September 2010 and 22 February 2011. Although the September earthquake caused limited to no damage to most of the churches [Anagnostopoulou et al., 2010], the damage observed by the authors was a consequence of the intense seismic activity that started in September 2010.

As shown in Figure 11 (a), the three major construction typologies for churches in the Canterbury region are timber, stone masonry and brick masonry, with about $10 \%$ of the buildings using other materials. More than half of the surveyed churches (57\%) received a green placard from the structural inspectors (see Figure 11 (b)). The FFU classification of the Italian survey form (see Figure 11 (c)) has the same objective as does the placard classification and it is interesting to notice the good correlation between the two parameters (see Figure 12 (a)). The number of churches with different classification using the two procedures is only $9 \%$ of the total (see Table 1 ). Note that the NZ classification was made by multiple teams of inspectors, while the FFU classification was made entirely by the same inspector. Given the fact that the FFU has 6 categories, as distinct from the three colours of the placards, only the green/Safe and 
red/Unsafe and Unsafe due to external Causes classifications are directly comparable. The percentage of churches with a green placard (57\%) is almost the same as was classified as Safe (60\%), and the percentage of churches with a red placard (22\%) is similar to the sum of the Unsafe and the Unsafe due to external causes categories (25\%). The Partially Safe classification was not used because of the comparatively simple architecture and small size of the churches that were surveyed in Christchurch when compared with Italian churches, meaning that generally when a church was damaged in the Canterbury earthquakes the whole building was affected. Following the policy used by the NZ inspectors, no Temporarily Unsafe classifications were used, as the major effort to institute structural interventions was undertaken within the Christchurch CBD, and although the main churches such as the Anglican Cathedral located in Cathedral Square at the centre of the Christchurch CBD and the Basilica of the Blessed Sacrament located in Barbados Street were subjected to thorough studies [Lester et al., 2012], the rest of the churches were assessed by consulting engineering companies but no further studies (non-destructive tests, numerical simulations, etc.) were carried out. A common example of each classification given by the NZ authorities can be seen in Figure 13.

The statistics associated with the other parameter from the Italian survey form, $i_{d}$, are shown in Figure 11 (d). As explained above, the inspector has to assign a level of damage, ranging from 0 to 5 as described in [Grunthal et al., 1998], to each of the activated macroelement. The description of each damage grade in [Grunthal et al., 1998 ] is very specific but this task is inevitably subjective and depends on the surveyors' experience. The first third of the total number of churches was inpected by two surveyors, which led consensual decision, whilst the other two thirds were surveyed by only one of them, meaning that the same criteria was roughly applied to all inspected buildings. Another challenge was the assessment of buildings only through the exterior 
when the interior was unsafe, situation that did not led to unreliable data due to two main reasons: the architecture of the churches follow the same pattern in all of the Canterbury region, as discussed next, and the macroelements present only in the interior of the churches, related to arches and vaults, are not available; when the church was unsafe to the point of preventing the surveyor to go inside, or even nearby, the damage in the macroelements was clearly visible from the outside. Keeping this in mind, the damage index was divided into three intervals with the objective of obtaining a single colour for each interval, therefore defining the amount of damage for each classification. It is important to emphasize that usually when the $i_{d}$ is higher than 0.30 the church is classified as unfit for use [Lagomarsino, 2011]. In Figure 12 (b) and (c) it is shown that, globally, the set of intervals proposed provides sets that are similar to those obtained from the placard data, even if the agreement is not perfect. The differences between the two classification schemes are due to the dissimilar nature of the classifications: the placards define the hazard of entering or re-occupying the building, regardless of the general amount of damage; while the $i_{d}$ parameter is derived from a systematic methodology that classifies the global damage of the structure. From a practical perspective what occurred during survey inspections was that churches with only non-structural damage (such as loss of plaster or damage sustained to ornamental elements) were assigned a yellow placard and a low value of $i_{d}$, and undamaged churches located near unstable slopes or heavily damaged buildings (see Figure 14) were assigned a red placard and a zero $i_{d}$, which are opposing classifications.

The scenarios discussed above justify the percentage of yellow and red placarded buildings associated with the lowest damage interval, where conceptually only green placards should be found, and the data presented in Figure 12 (c) confirm this observation because the 'Unsafe due to External Causes' and 'Safe with 
Precautions' classifications are in the lowest interval. As for the percentage of green and red placards in the $0.10<i_{d}<0.40$ interval and the percentage of yellow placards in the $i_{d}>0.40$, these data may be due to the ambiguous nature of the placard classification, which depends on the inspector's judgement, or due to the fact that the damage index classification is inappropriate. The Italian recommendations, based on previous experience with damage assessment, suggest that as a method to eliminate the variability associated with personal judgement, all churches assigned a value of $i_{d}$ above a prescribed level be considered Unsafe (the recommended value would be 0.40 according to the application in NZ). Still, it is striking that the data presented in Figure 12 (a) provide good agreement between the NZ and the Italian approaches, indicating that an approach based on the damage index in order to allow or restrain the use of a building or prioritize its intervention is possibly unreliable.

\section{Stone churches}

Given the different dynamic characteristics of the three principal church typologies found in the Canterbury region (see Figure 7), the statistical analysis described above was extended by separately analysing the results obtained for each individual typology and comparing these findings with the overall results. Starting with the placard classification (see Figure 15 (a)), more than half of the stone churches (52\%) were assigned a red placard and only 16\% of the churches had a green placard assigned. From the FFU classification shown in Figure 15 (b) good agreement was obtained for the red placards only, as the Safe classification was $10 \%$ higher than the green placard classification (26\% vs. 16\%), and Figure 16 (a) shows that these $10 \%$ were assigned a yellow placard. It is possible that the lower percentage of green placards in comparison with the FFU Safe classification could be due to the low confidence of the inspectors of 
the Civil Defence in the seismic capacity of stone masonry buildings, even in the case of low damage. For the other FFU classifications, good correlation was found when compared to the corresponding placards. It is also important to recognise that the inspections and the classifications were performed in different contexts, as classifying damaged structures immediately after an earthquake for the purpose of determining whether the building is safe for people to re-enter can result in a more conservative judgement than would be assigned when undertaking a damage assessment for research purposes several weeks after the earthquake.

The division of the damage index $i_{d}$ into three intervals in order to define a value for each colour placard for stone churches was undertaken in a slightly different manner to the procedure adopted for the complete dataset accounting for all typologies (see Figure 16 (b)). The interval for the green placards was assigned an elevated upper limit (0.15 instead of 0.10$)$ and the interval for the red placards was assigned a decreased lower limit ( 0.30 instead of 0.40$)$. The reason for this decrease could be the same as the above; the inspectors might have assigned a red placard even if the damage was moderate, because their trust in stone masonry could be lower than in brick masonry, even if this could not be confirmed. The absence of clear demarcation between the three placard designations is readily identifiable, particularly when the $i_{d}$ value is related to the FFU, as show in Figure 16 (c). As the percentage of Safe classifications is higher than the percentage of green placards, the middle interval $\left(0.15<i_{d}<0.30\right)$ has a small percentage of Safe classifications, as opposed to the information presented in Figure 16 (b), where no green placards are found in the middle interval. It is also shown in Figure 16 (c) that the percentage of red placards in the first interval is due to external causes, and therefore the $i_{d}$ of these churches can be quite low. 


\section{Brick churches}

The brick churches were less damaged than the stone churches, but also exhibited poor performance during the earthquakes. Figure 17 (a) shows that a red placard was assigned to $38 \%$ of the churches, while a yellow placard was assigned to $43 \%$ of the churches. The percentage of red placards assigned for this typology was smaller than the percentage assigned for the stone churches, but the sum of red and yellow placards was similar for both masonry typologies and exceeded $80 \%$.

The FFU classification (see Figure 17 (b)) gave good agreement with the placard classification (Figure 18 (a)) with the same percentage of green placards and Safe classifications assigned to the same churches. The percentage of red placards was $5 \%$ lower than was recorded for the Unsafe category, and therefore the percentage of yellow placards was 5\% higher than recorded for the 'Safe with Precautions' category. Also, these classifications were not assigned to the same churches as the red placard percentage was lower than the percentage assigned as Unsafe and there was also 5\% having a 'Safe with Precautions' classification in the red placard column (see Figure 18 (a)).

The three suggested intervals for the $i_{d}$ (see Figure 18 (b)) are the same as those used for the entire dataset of churches, and therefore are slightly different from those used for the stone churches. It was established that in order to be assigned a green placard the brick churches required a lower $i_{d}$ value in comparison to the corresponding value for stone churches, as the interval for brick churches is $i_{d}<0.10$. For the red placards the inverse occurs and the brick churches required a higher value of $i_{d}>0.40$, instead of the 0.3 value used for stone churches. These modifications indicate that stone churches can withstand higher levels of damage than can brick churches in order to be assigned a green placard, but sustain lower levels of damage in order to be assigned a 
red placard. Similar results are presented in Figure 18 (c), although the correlation between the colour placards and the FFU classification is not exact.

\section{Timber churches}

The timber churches had the best overall performance, with no structural damage and, as can be seen in Figure 19 (a) and (b), 94\% of the churches were assigned a green placard or Safe classification. The single red placard assigned to a timber church was due to external causes, such that there were no Unsafe classifications and only 'Unsafe due to External Causes'. Finally, the yellow placard, with the same percentage as the 'Safe with Precautions’ category was due to non-structural damage, being mainly cracking of the inside or outside plaster.

The $i_{d}$ parameter was computed and taken into consideration in Figure 11 (d), although the seismic behaviour of the timber churches poorly fits the macroelement concept, which is based on the division of a church into a given number of elements that have a nearly independent seismic response as is typical of masonry churches [Doglioni et al., 1994; Giuffrè, 1999]. This disparity does not indicate that the architectural elements are absent as the church can still be divided into the same macroelements, but instead that the structural components are less likely to be activated individually as in masonry churches, because of the required localization of deformation.

\section{Activated collapse mechanisms}

The data on the timber churches are not included in the results presented in Figure 20

(a) and (b) regarding the failure mechanisms observed. A comparison between the Possible and Activated collapse mechanisms can provide valuable information. Certain macroelements represent basic architectural components of all churches and there is no surprise that mechanisms 1,2 and 3 , which are related to the church facade, can be 
activated in all stone and brick churches (see Figure 20 (a)). The same comment applies to mechanism 6 , which is related to the lateral walls of the churches, to mechanism 19 which is related to the roofing elements, and to mechanism 25 which is related to irregularities in elevation.

There are other possible mechanisms present in more than $70 \%$ of the churches: $5,16,17,21$ and 26 . The first of these mechanisms is associated with transversal response of the side walls, while the next three mechanisms are all related to the apse. The last mechanism is associated with the response of non-structural elements that can be projected such as pinnacles and statues. In opposition to these mechanisms, a considerable number of mechanisms were possible in less than $10 \%$ of the surveyed churches (mechanisms $7,8,9,12,14,15,18,24)$ as these mechanisms are primarily related to columns in the main nave, and vaults in any of the naves, apses, chapels and domes. This clear difference between a group of mechanisms available in more than $70 \%$ of the churches and another available in only $10 \%$ is due to the architectural similarity of the churches, independent of the construction material. A typical church in the Canterbury region has only one nave, porch, presbytery and apse and no chapels, columns, vaults or domes.

In order to determine the most vulnerable mechanisms, it is necessary to take into account the average damage classification given to each mechanism, according to the EMS-98 proposal [Grunthal et al., 1998], as well as the average activation value of that mechanism when it was available (see Figure 20 (b)). This last parameter is relevant when analysing the mechanisms with the highest average damage values, as mechanisms 8 (average value of 4.5), 15 (average value of 4.0) and 14 (average value of 4.0) are related to the vaults, dome and lantern, which are elements present only in the heavily damaged Cathedral of the Blessed Sacrament. Therefore, the most vulnerable 
mechanisms should be those that are activated in most churches and exhibit a considerable average damage value, and these mechanisms can be found in the shaded area of Figure 20 (b): seven mechanisms (2, 6, 16, 19, 21, 25, 26) are activated in more than $50 \%$ of the churches, with an average damage value greater than 1.5. Mechanism 6, which is shear in the longitudinal walls (see Figure 21 (a) and (b)) stands out as the most vulnerable mechanism (activated in $83 \%$ of the churches, with an average damage value of 2.34), followed by mechanism 19 (hammering of the roof, activated in $67 \%$ of the churches with an average damage value of 1.94, see Figure 21 (c) and (d)) and mechanism 2 (overturning of the top of the facade, activated in $60 \%$ of the churches with an average damage value of 2.25, see Figure 21 (e) and (f)).

Assigning a damage level to each stone and clay brick church (0 if $i_{d}<0.05,1$ if $0.05 \leq i_{d}<0.25,2$ if $0.25 \leq i_{d}<0.40,3$ if $0.40 \leq i_{d}<0.60,4$ if $0.60 \leq i_{d}<$ 0.80, 5 if $i_{d} \geq 0.80$ ) as defined in [Lagomarsino and Podestà, 2004b], see Figure 22 (a) and (b), the higher vulnerability of stone churches, when compared to clay brick ones, appears even more evident. It is also possible to compare the vulnerability of the New Zealand churches with the ones damaged from the 26 September 1997 Umbria-Marche earthquake in Italy [Lagomarsino and Podestà, 2004b]. Considering only the areas with an intensity $I=V I I I$ in Umbria-Marche, a higher percentage of stone churches in New Zealand present level 1 damage (35\% against 10\% in Umbria and 8\% in Marche) but less stone churches have levels 2, 3, 4 and 5 of damage in New Zealand. As for the clay brick churches of New Zealand the scenario is similar with exception of level 3 of damage where the percentage is roughly $29 \%$ in all the churches in both countries.

\section{Conclusions}

The reported damage survey involved recording the structural damage found after the 
earthquakes in the Canterbury region of NZ in September 2010 and February 2011 in almost all churches built before 1938 [Hamilton and Hamilton, 2008], leading to a total of 112 church buildings contained within the survey dataset. The only pre-1938 churches that were omitted from the survey were those that were already demolished and those that were damaged to such an extent that it was unsafe to perform an assessment. The survey exercise entailed recording the placard that was assigned by the NZ authorities and completing the Italian survey form for churches [Civil Protection Department, 2006]. The survey allowed conclusions to be reached regarding the structural performance of the church buildings and use of the classification procedures adopted by both local authorities and by the Italian Civil Protection Department.

From statistical analysis of the obtained data it was established that a general comment on the overall performance of the churches was potentially misleading due to the existence of three main church typologies (stone, clay brick and timber), that exhibited different seismic characteristics. When analysing the typologies separately, the timber churches were found to have had an excellent seismic performance, while the stone and clay brick churches clearly performed unsatisfactorily. Only non-structural damage such as damaged plaster in the interior was registered during the assessment of timber churches, with $94 \%$ of these churches having received a green placard. The inverse scenario was found in the stone and clay brick churches, with $80 \%$ of those churches being assigned either a yellow or red placard.

The Italian FFU classification was used during the survey of the churches, which has the same purpose as the colour placards of the NZ authorities, together with the damage index $i_{d}$ that defines and quantifies the possible and activated macroelements. The FFU classification is slightly different from the three colour placards used in NZ, with more possible classifications (Safe, Unsafe, Partially Safe, Safe with Precautions, 
Temporarily Unsafe and Unsafe due to External Causes). The correlation between the two classification systems was considered to be good when the placard colour was compared with the sum of more than one FFU classification, e.g. the red placard was compared with the sum of Unsafe and Unsafe due to External Causes (e.g. slope instability or heavily damaged surrounding buildings).

The damage index $i_{d}$ was computed in accordance with the macroelement concept, with the objective of determining a hierarchy of remediation interventions. It is clear from the data collected that the most damaged churches had a higher $i_{d}$ value in general. This parameter varies between 0 and 1 and, with the objective of obtaining limit values for each placard classification (green, yellow and red), intervals of damage index values were defined. The resulting recommendations were for similar intervals to be adopted for the stone and clay brick churches, with green placards being assigned to churches with an $i_{d}$ value of less than 0.15 (stone churches) or 0.10 (clay brick churches), and red placards being assigned to churches that had received $i_{d}$ values greater than 0.30 (stone churches) or 0.40 (clay brick churches). This demarcation was not perfect because it did not coincide with the FFU or placard classification, on a direct case by case comparison. This lack of correlation may be due to subjectivity in the assignment process of placards, which is dependent on the inspector's judgment, to the designation of red placards due to external causes, which is not considered in the damage index classification, or because the damage index procedure is unable to correctly define the vulnerability of the churches. In order to avoid a lack of correlation between the FFU and $i_{d}$, the Italian authorities have proposed to classify churches with damage index values above 0.30 as Unsafe, but the present results indicate that the damage index should be used carefully. 
From analysis of the possible collapse mechanisms (macroelements) it was established that in the Canterbury region of NZ some mechanisms are rarely present (encountered in less than $10 \%$ of the churches) and these macroelements are related to columns in the main nave, vaults and chapels, confirming the simplicity of the architecture of NZ churches. Other collapse mechanisms were possible in all churches, such as those associated with facades and longitudinal walls, as well as the hammering of roofs and interaction near plano-altimetric irregularities. Also, there were no cases where the available collapse mechanisms defined in the Italian procedure were insufficient due to a high complexity of the church.

The most vulnerable collapse mechanisms found were shear damage in the longitudinal walls, hammering of the roof and overturning of the top of the facade.

\section{References}

Allen, J., Ashford, S., Bowman, E., Bradley, B., Cox, B., Cubrinovski, M., Green, R. A., Hutchinson, T., Kavazanjian, E., Orense, R., Pender, M., Quigley, M., and Wotherspoon, L. [2010] "Geotechnical Reconnaissance of the 2010 Darfield (Canterbury) Earthquake," Bulletin of the New Zealand Society for Earthquake Engineering 43 (4), 243-320.

Anagnostopoulos, S., and Moretti, M. [2006] "Post-earthquake emergency assessment of building damage, safety and usability - Part 2: Organisation.," Soil Dynamics and Earthquake Engineering 28 (2008), 233-244.

Anagnostopoulou, M., Bruneau, M., and Gavin, H. P. [2010] "Performance of Churches During the Darfield Earthquake of September 4, 2010," Bulletin of the New Zealand Society for Earthquake Engineering 43 (4), 374-381.

Angeletti, P., Ferrini, and Lagomarsino, S. [1997] "Survey and evaluation of the seismic vulnerability of the churches: and application in Lunigiana and Garfagnana (in Italian)," Proc. of the 8th National Conference: Earthquake Engineering in Italy, Palermo, 1077-1084.

Applied Technology Council (ATC). (1989). "ATC-20: Procedures for Post-earthquake Safety Evaluation of Buildings ATC-20" Redwood City, CA, pp. 152. 
Applied Technology Council (ATC). (1995). "ATC-20-2: Addendum to the ATC-20

Post-earthquake Building Safety Procedures" Redwood City, CA, pp. 95.

Bradley, B. A., and Cubrinovski, M. [2011] "Near-Source Strong Ground Motions

Observed in the 22 February 2011 Christchurch Earthquake," Bulletin of the

New Zealand Society for Earthquake Engineering 44 (4), 181-194.

Canterbury Earthquake Recovery Authority. "LandCheck" [2011] accessed 27/01/2012 Available from http://www.landcheck.org.nz/

Christchurch City Libraries. [2006] accessed 27/01/2012 Available from

http://christchurchcitylibraries.com/heritage/earlychristchurch

Civil Protection Department [2006] "Scheda per il rilievo del danno ai beni culturali Chiese."

Cubrinovski, M., Bradley, B., Wotherspoon, L., Green, R., Bray, J., Wood, C., Pender, M., Allen, J., Bradshaw, A., Rix, G., Taylor, M., Robinson, K., Henderson, D., Giorgini, S., Ma, K., Winkley, A., Zupan, J., O'Rourke, T., DePascale, G., and Wells, D. [2011] "Geotechnical Aspects of the 22 February 2011 Christchurch Earthquake," Bulletin of the New Zealand Society for Earthquake Engineering 44 (4), 205-226.

Dizhur, D., Ingham, J., Moon, L., Griffith, M., Schultz, A., Senaldi, I., Magenes, G.,

Dickie, J., Lissel, S., Centeno, J., Ventura, C., Leite, J., and Lourenco, P. [2011] "Performance of Masonry Buildings and Churches in the 22 February 2011 Christchurch Earthquake," Bulletin of the New Zealand Society for Earthquake Engineering 44 (4), 279-296.

Doglioni, F., Moretti, A., Petrini, V., and Angeletti, P. (1994). Le chiese e il terremoti: dalla vulnerabilità constatata nel terremoto del Friuli al miglioramento antisismico nel restauro, verso una politica di prevenzione, Trieste, Italy: Edizioni Lint.

GeoNet. "Aftershocks" [2011a] accessed 27/01/2012 Available from http://www.geonet.org.nz/canterbury-quakes/aftershocks/

GeoNet. "Historic Earthquakes" [2011b] accessed 27/01/2012 Available from http://www.geonet.org.nz/earthquake/historic-earthquakes/index.html Giuffrè, A. (1999). Letture Sulla Meccanica delle Murature Storiche, Rome, Italy: Kappa.

Gledhill, K., Ristau, J., Reyners, M., Fry, B., and Holden, C. [2010] "The Darfield (Canterbury) Earthquake of September 2010: Preliminary Seismological 
Report," Bulletin of the New Zealand Society for Earthquake Engineering 43 (4), 215-221.

Grimaz, S. [2011] "Management of urban shoring during a seismic emergency: advances from the 2009 L'Aquila (Italy) earthquake experience," Bollettino di Geofisica Teorica ed Applicata 52 (2), 341-355.

Grunthal, G., Musson, R. M. W., Schwartz, J., and Stucky, M. (1998). European Macroseismic Scale 1998 (EMS-98), European Seismological Commission, Working Group Macroseismic Scales, Luxembourg.

Guerreiro, L., Azevedo, J., Proença, J., Bento, R., and Lopes, M. [2000] "Damage in ancient churches during the 9th of July 1998 Azores earthquake," Proc. of the 12th World Conference on Earthquake Engineering Auckland, New Zealand.

Hamilton, D., and Hamilton, J. (2008). Early churches in and around Christchurch, Christchurch: Judith and Derek Hamilton.

Lagomarsino, S. [2012] "Damage assessment of churches after L'Aquila earthquake (2009)," Bulletin of Earthquake Engineering 20 (1), 73-92.

Lagomarsino, S., and Podestà, S. [2004] "Seismic Vulnerability of Ancient Churches: I. Damage Assessment and Emergency Planning," Earthquake Spectra 20 (2), 377394.

Lagomarsino, S., and Podestà, S. [2004a] "Damage and vulnerability assessment of churches after the 2002 Molise, Italy, earthquake.," Earthquake Spectra 20 (S1), S271-S283.

Lagomarsino, S., and Podestà, S. [2004b] "Seismic Vulnerability of Ancient Churches: II. Statistical Analysis of Surveyed Data and Methods for Risk Analysis.," Earthquake Spectra 20 (2), 395-412.

Lester, J., Brown, A., and Ingham, J. [2012] "Christchurch Cathedral of the Blessed Sacrament: Lessons learnt on the Stabilization of a Significant Heritage Building," Proc. of the 2012 NZSEE Conference, Christchurch, New Zealand.

Maugeri, M., Simonelli, A. L., Ferraro, A., Grasso, S., and Penna, A. [2011] "Recorded ground motion and site effects evaluation for the April 6, 2099 L'Aquila earthquake.," Bulletin of Earthquake Engineering (9), 157-179.

New Zealand Legislation. "Civil Defence Emergency Management Act 2002" [2002] accessed 27/01/2012 Available from http://www.legislation.govt.nz/act/public/2002/0033/latest/DLM149789.html 
New Zealand Legislation. "Building Act 2004 No 72" [2004] accessed 27/01/2012 Available from http://www.legislation.govt.nz/act/public/2004/0072/latest/viewpdf.aspx

New Zealand Society for Earthquake Engineering [2009] "Building Safety Evaluation During a State of Emergency - Guidelines for Territorial Authorities."

NZ Government. "Wellington and Christchurch's earthquake risk" [2011] Available from http://blog.teara.govt.nz/2011/02/24/wellington-christchurchs-earthquakerisk/

NZ Police. "List of deceased" [2011] Available from http://www.police.govt.nz/listdeceased

NZ Treasury. "Government Budget" [2011] Available from http://www.treasury.govt.nz/economy/reports/econbrief-eice-10sep10.pdf

NZS 1170.5. (2004). "Structural Design Actions Part 5: Earthquake actions - New Zealand" Standards New Zealand: Wellington, New Zealand.

PapersPast [2010] "Official Report on Public Buildings, Star, Issue 6333, 3 September 1888," Star (6333).

Podestà, S., Brignola, A., Curti, E., Parodi, S., and Lemme, A. [2010] "Damage assessment and seismic vulnerability of churches: the Abruzzo earthquake (in Italian, with extended abstract in English)." Ingegneria Sismica XXVII (1), 2135.

Russell, A., and Ingham, J. [2010] "Prevalence of New Zealand's Unreinforced Masonry Buildings'." Bulletin of the New Zealand Society for Earthquake Engineering 43 (3, Sept.), 182-201.

Statistics New Zealand. [2006] accessed 27/01/2012 Available from http://www.stats.govt.nz/Census.aspx

Wood, P., Robins, P., and Hare, J. [2010] "Preliminary observations of the 2010 Darfield (Canterbury) earthquakes: an introduction.," Bulletin of the New Zealand Society for Earthquake Engineering 43 (4), i-iv. 


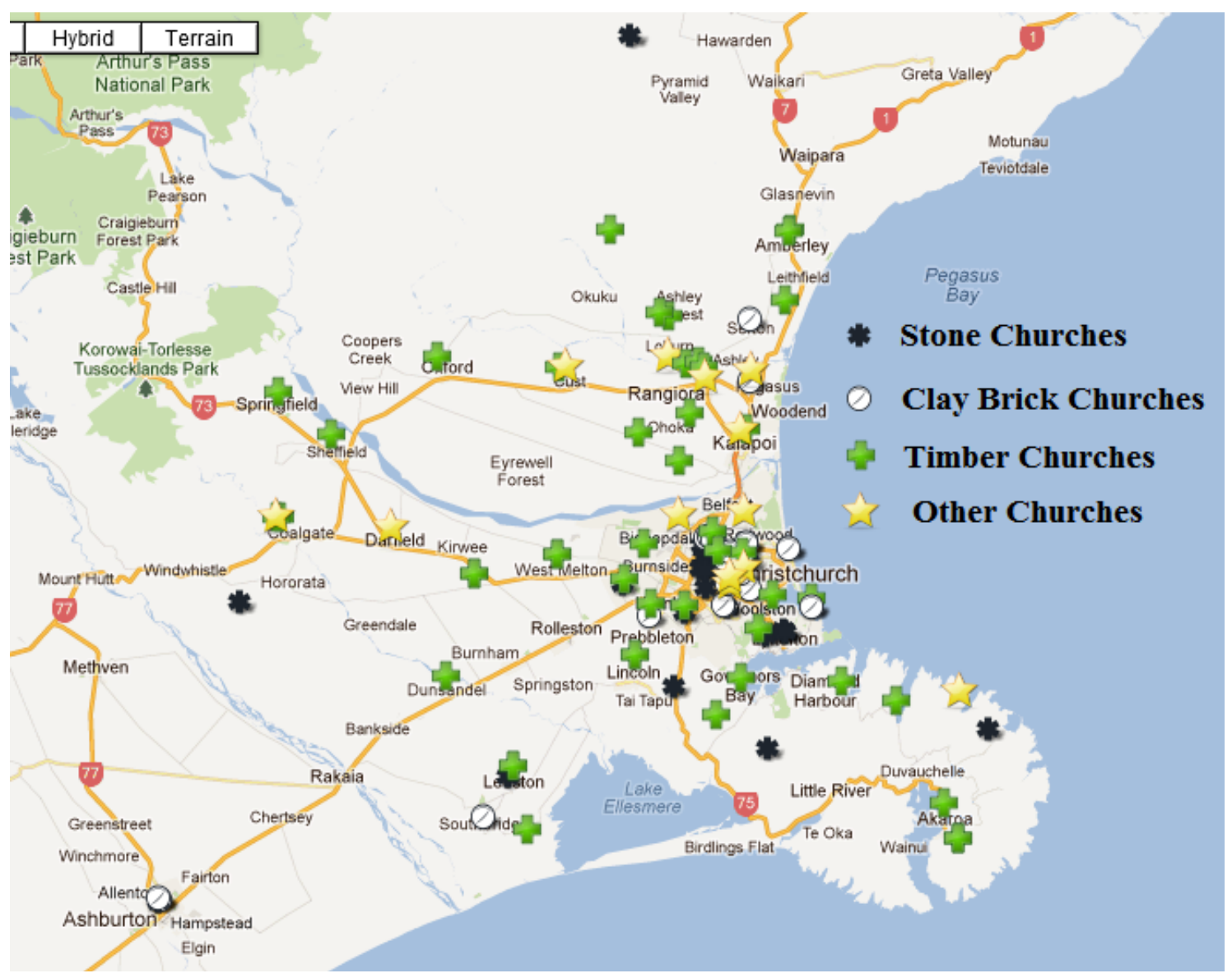

Figure 1 - Location of surveyed churches in the Canterbury District of New Zealand. 


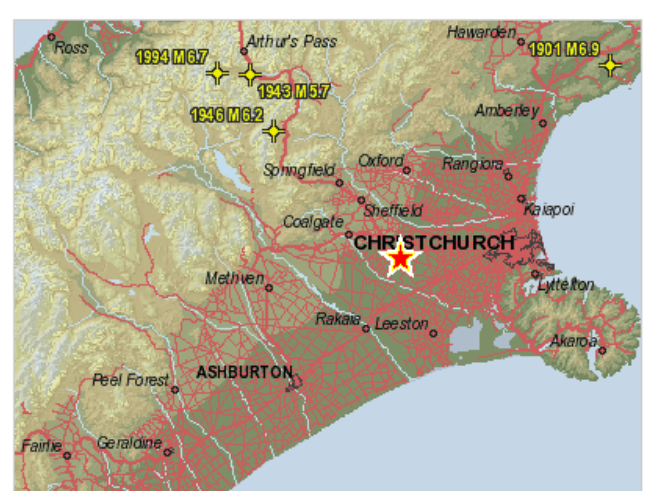

(a) earthquake location map

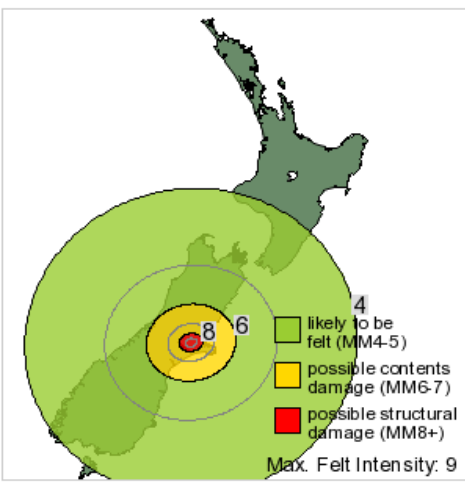

(b) isoseismal map

Figure 2 - Details of the 4 September 2010 earthquake [GeoNet, 2011a]. 


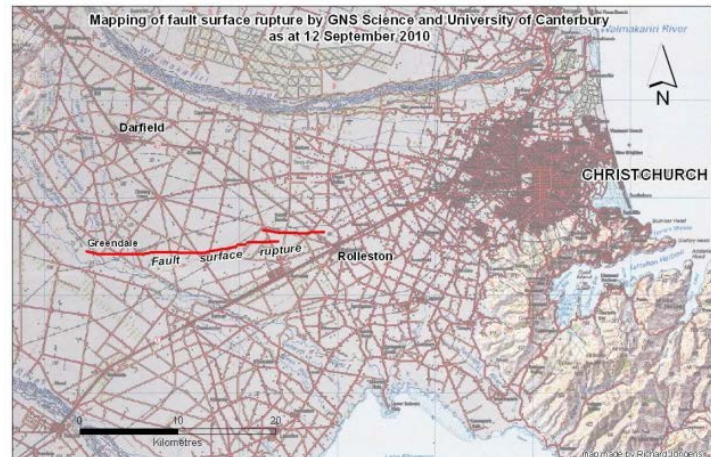

(a) total extension

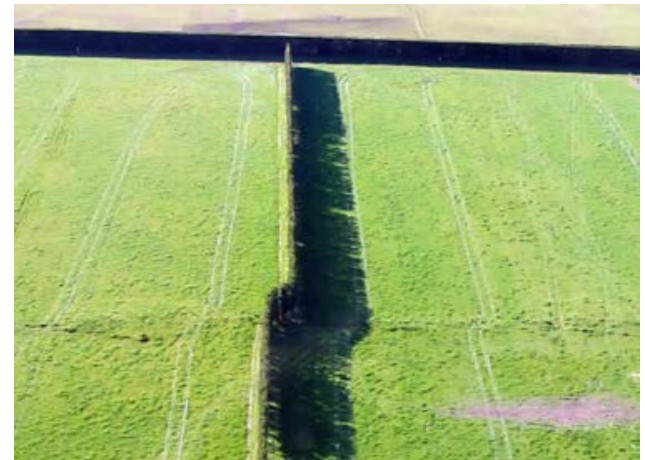

(b) aerial view

Figure 3 - Greendale Fault surface rupture [GeoNet, 2011a]. 


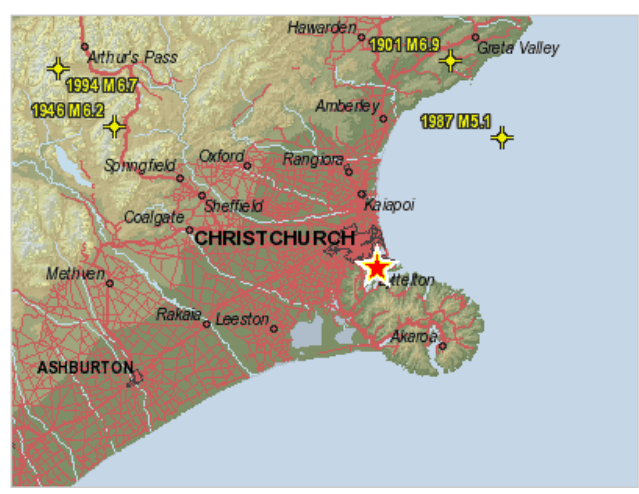

(a) earthquake location map

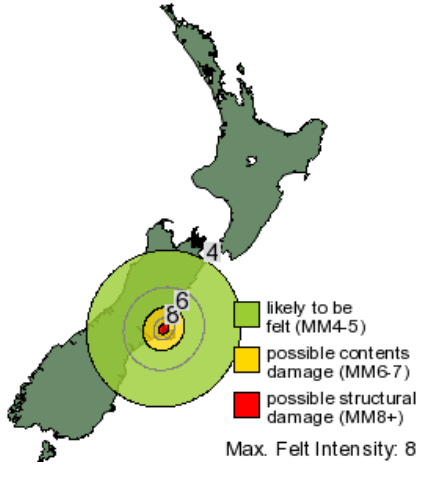

(b) isoseismal map

Figure 4 - Details of the 22 February 2011 earthquake [GeoNet, 2011a]. 


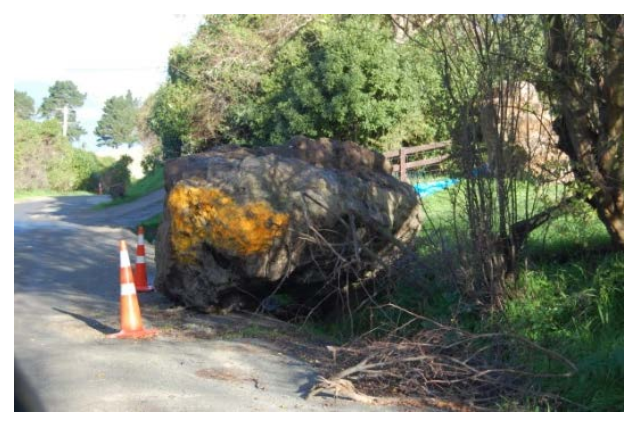

(a) example of a boulder that

rolled downhill

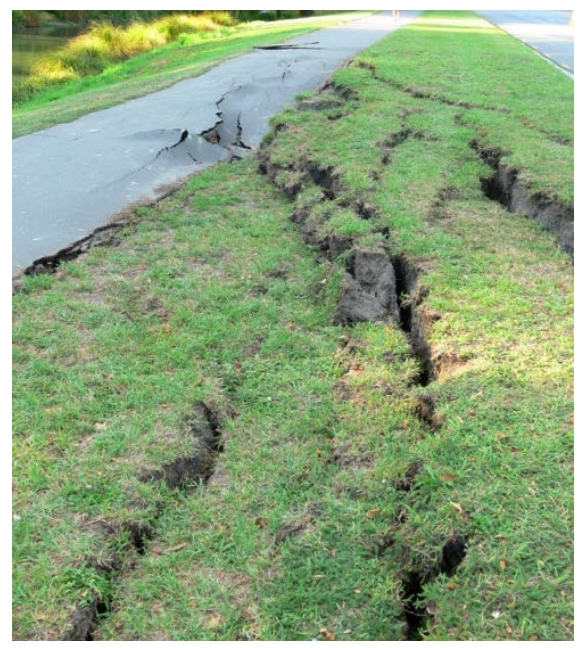

(c) lateral spreading along the

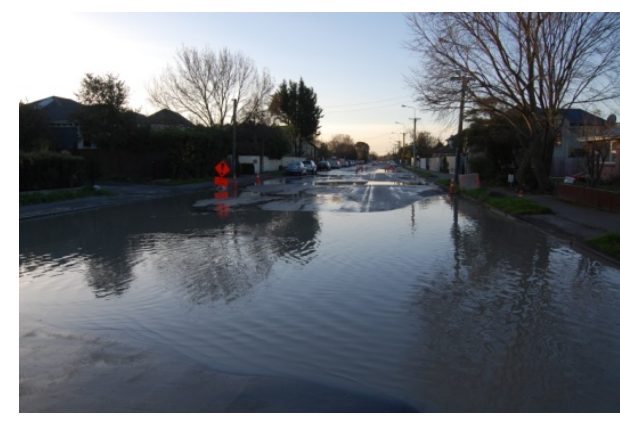

(b) liquefaction in the Christchurch City

centre

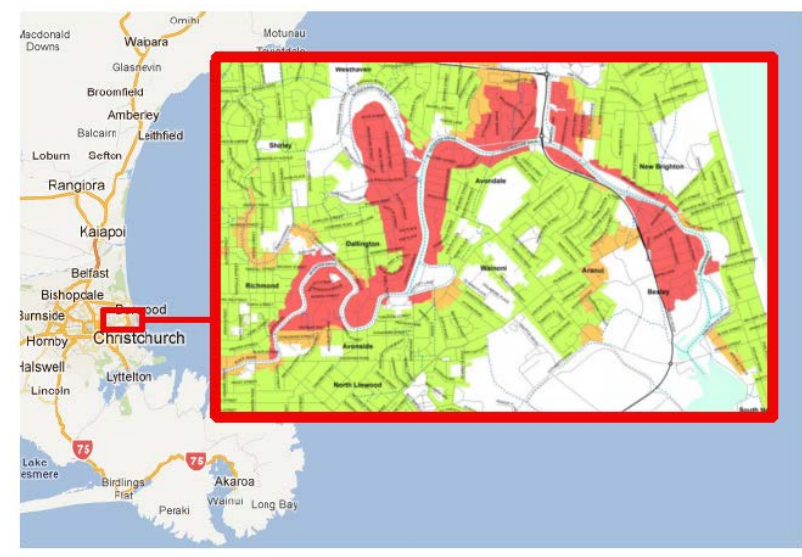

(d) CERA land classification map

[Canterbury Earthquake Recovery

Authority, 2011]

Figure 5 - Geotechnical phenomena due to the Canterbury earthquake sequence. 


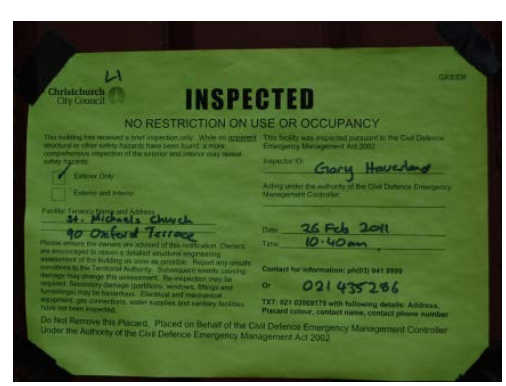

(a) green for inspected and safe to re-enter

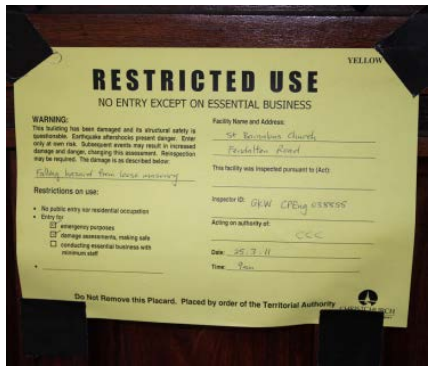

(b) yellow for restricted access

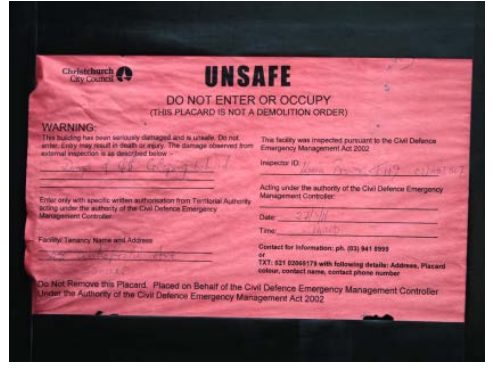

(c) red for unsafe

Figure 6 - Placards given to buildings after Level 1 and Level 2 assessment. 


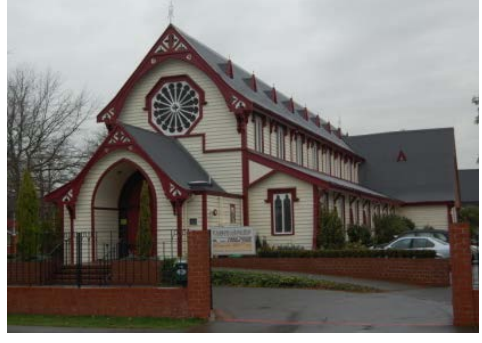

(a) timber church of St Andrews, Merivale, 1857

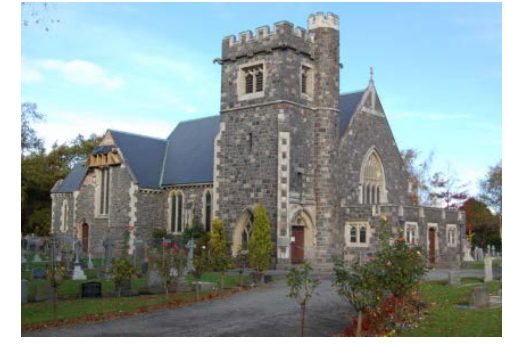

(b) stone church of St Peters, Upper Riccarton, 1876

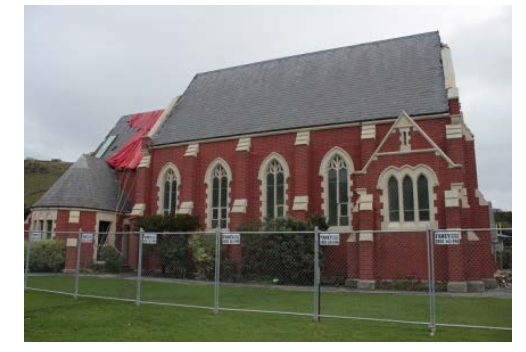

(c) clay brick church of Our Lady Star of the Sea, Sumner, 1912

Figure 7 - Church typologies found in the Canterbury region. 


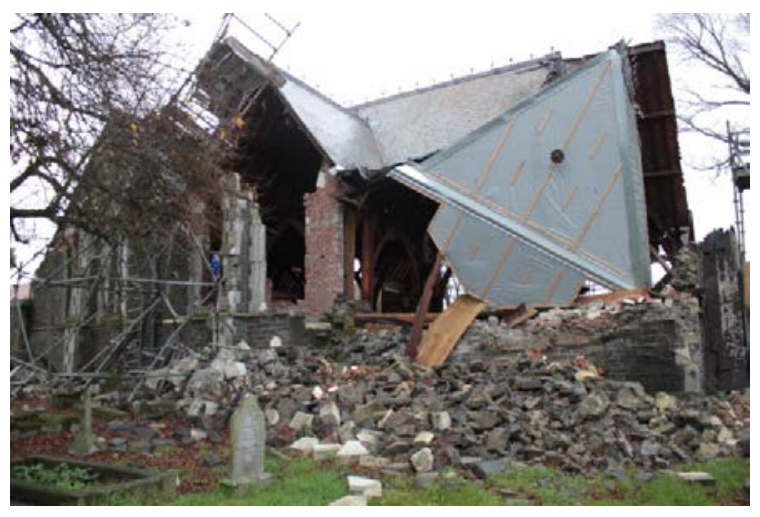

(a) exterior inspection only due to safety reasons (Holy Trinity, stone, Avonside)

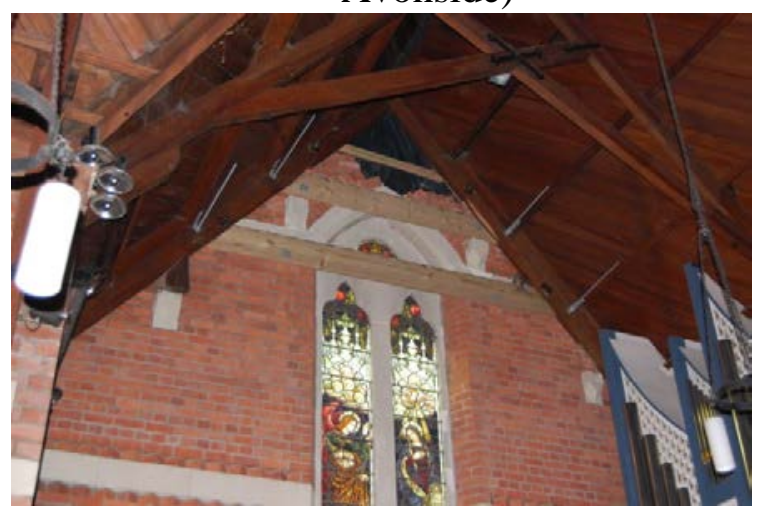

(c) interior inspection (stone church of St Peter's, stone and clay brick, Upper Riccarton)

Figure 8 - Visual inspection of churches.

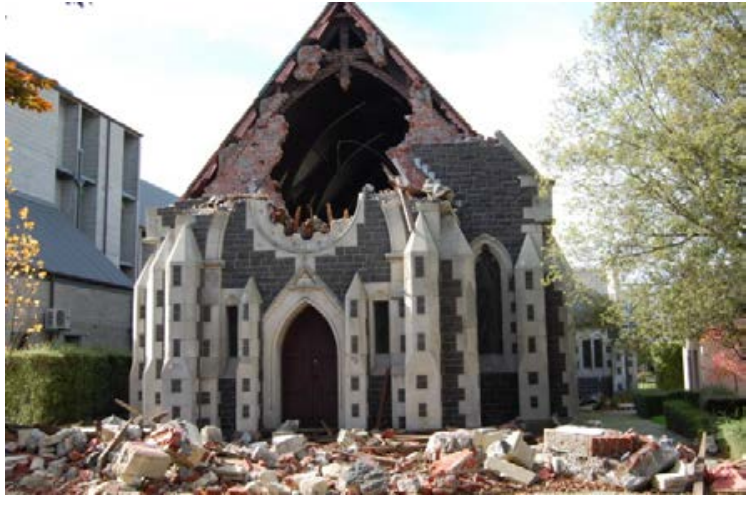

(b) exterior inspection only due to safety reasons (Rose Historic Chapel, stone,

CBD)

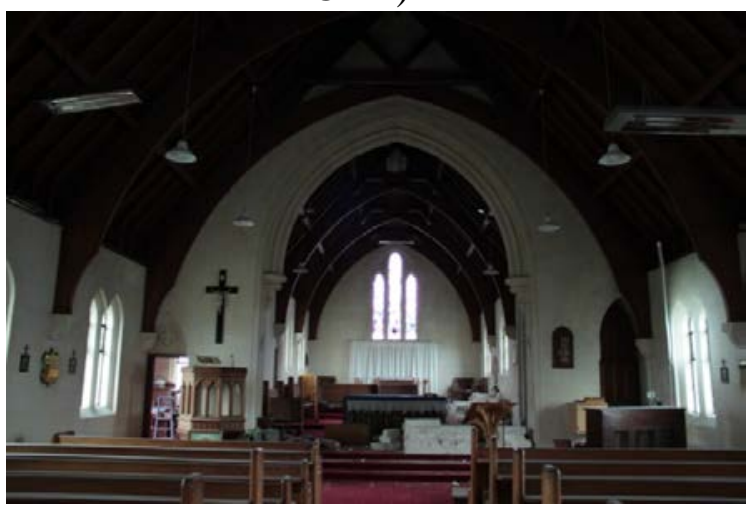

(d) interior inspection (St. Faith's, stone, New Brighton) 


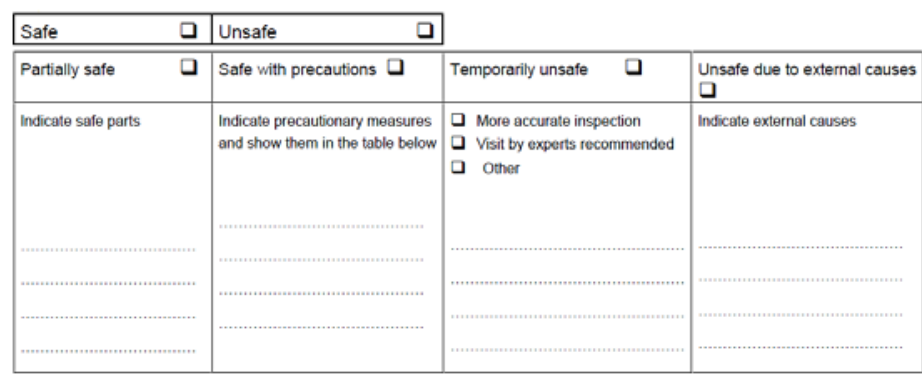

Figure 9 - Fitness For Use (FFU) classification in the Italian survey form for churches [Civil Protection Department, 2006]. 


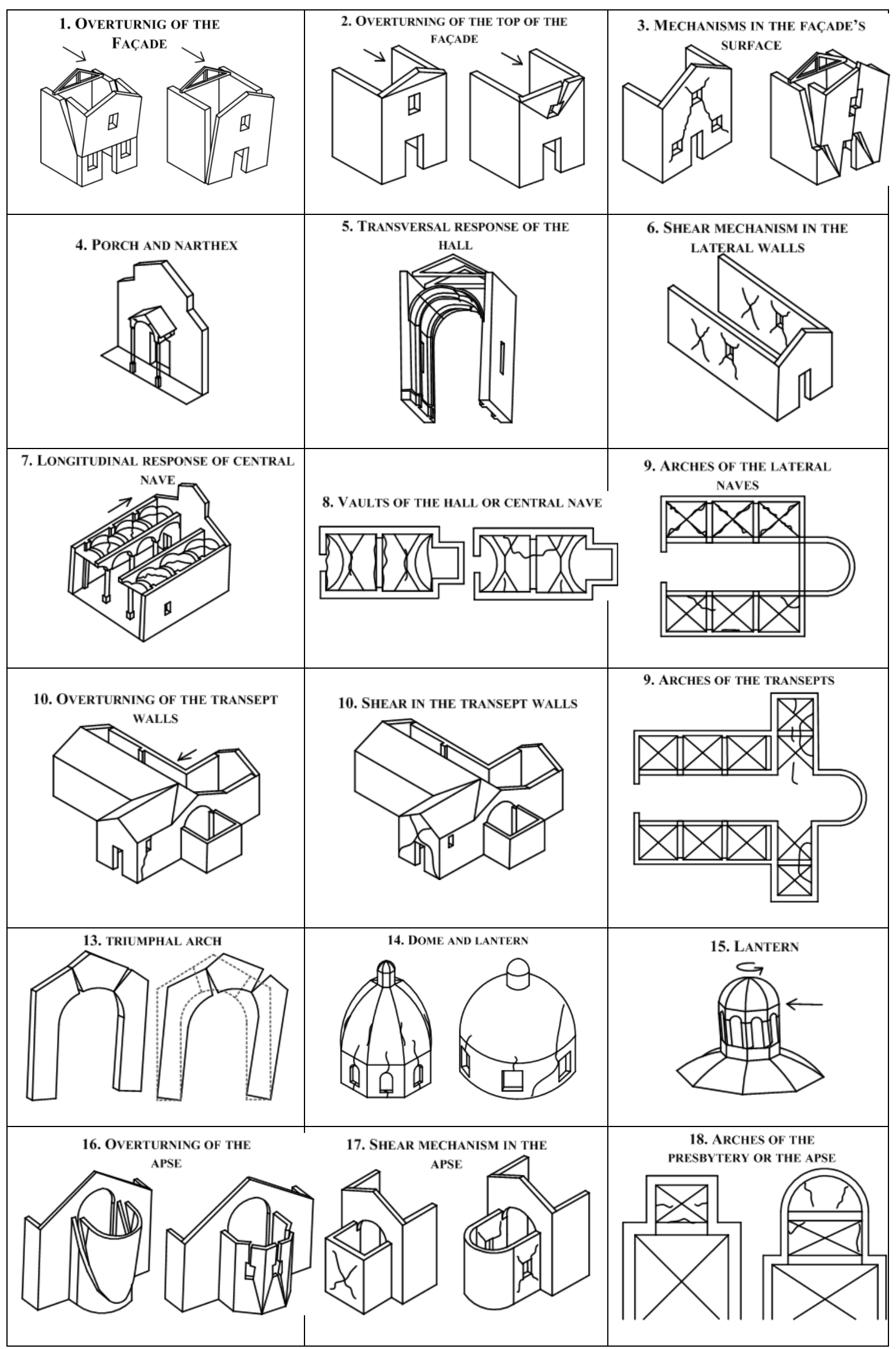




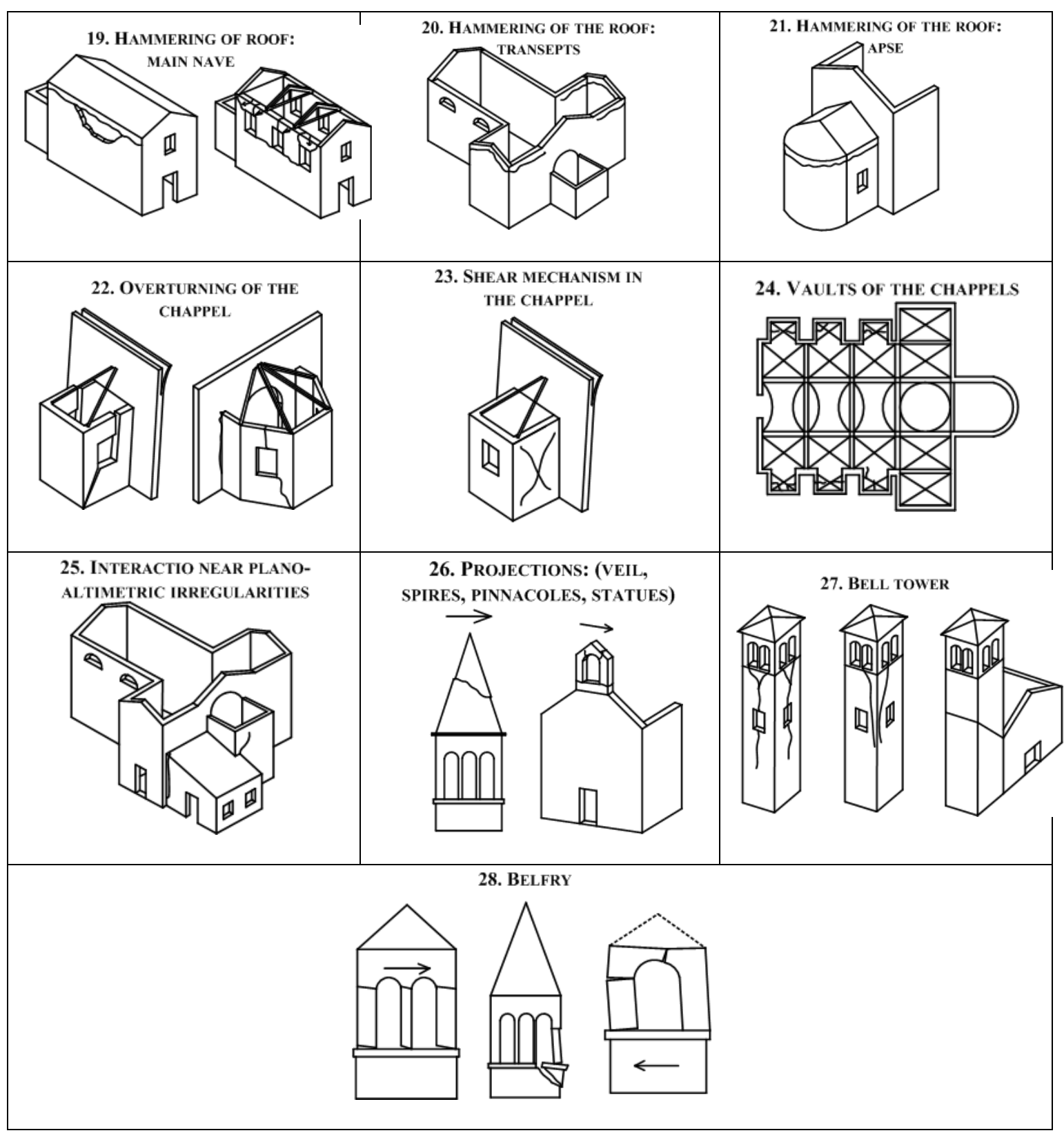

Figure 10 - Collapse mechanisms in the Italian survey form for churches [Civil Protection Department, 2006]. 


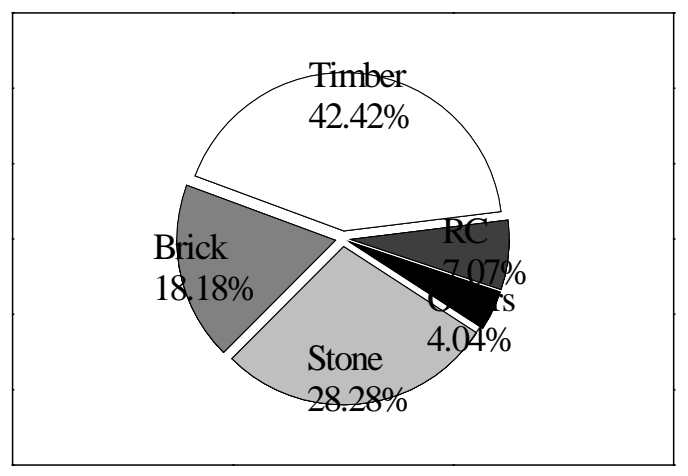

(a) typologies

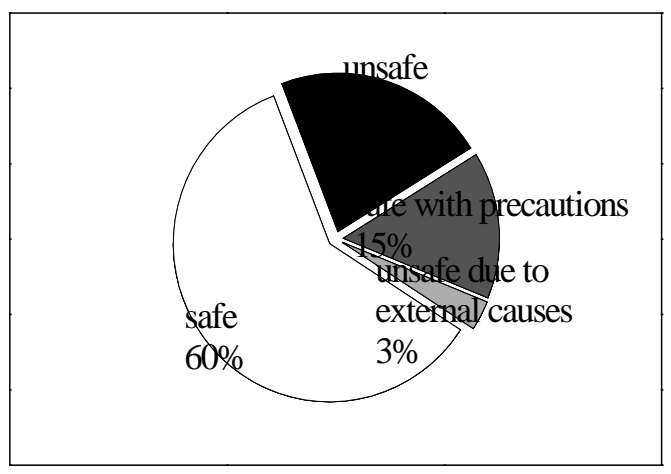

(c) FFU classification (Italian survey form [Civil Protection Department, 2006])

Figure 11 - Statistical data for all churches.

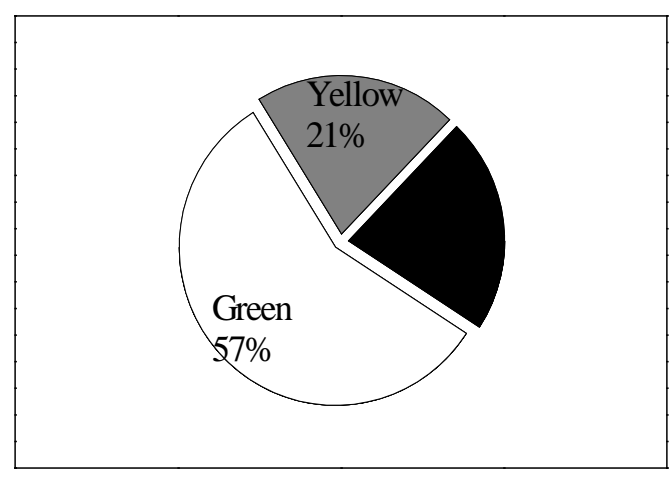

(b) placard classification

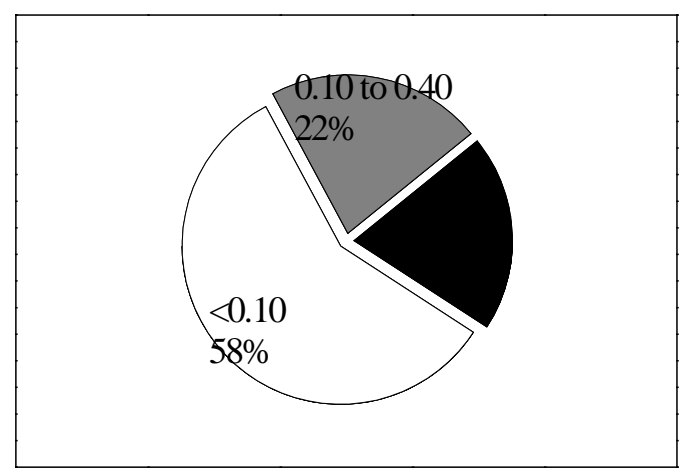

(d) damage index $\boldsymbol{i}_{\boldsymbol{d}}$ (Italian survey form) 


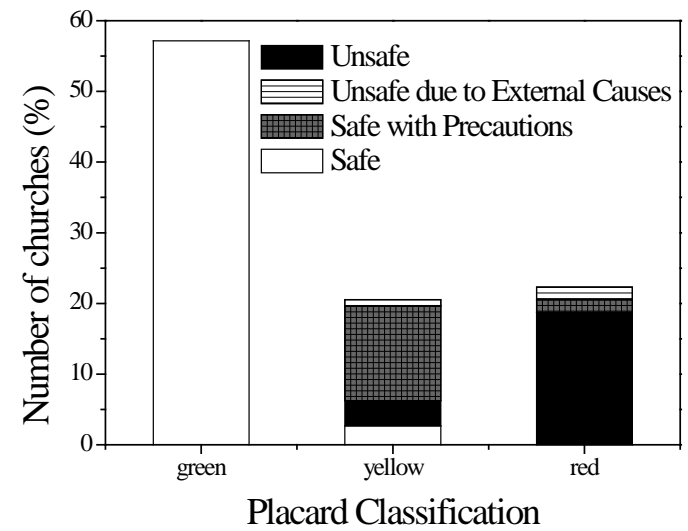

(a) correlation between the placard classification and the FFU classification

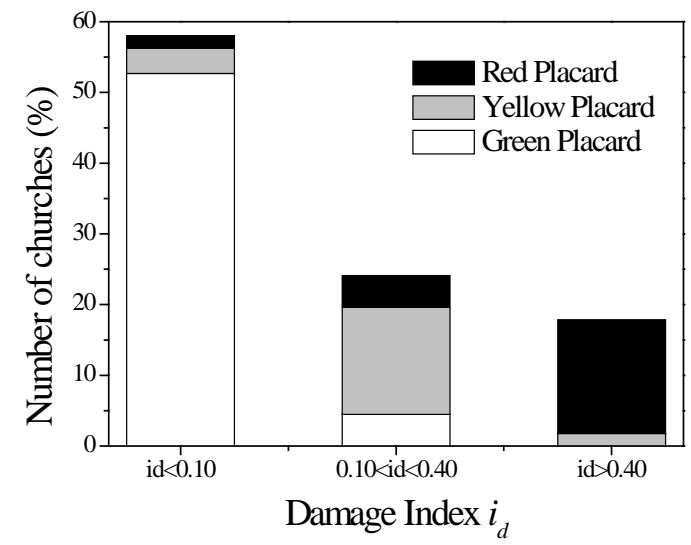

(b) correlation between the damage index $\boldsymbol{i}_{\boldsymbol{d}}$ and the placard classification

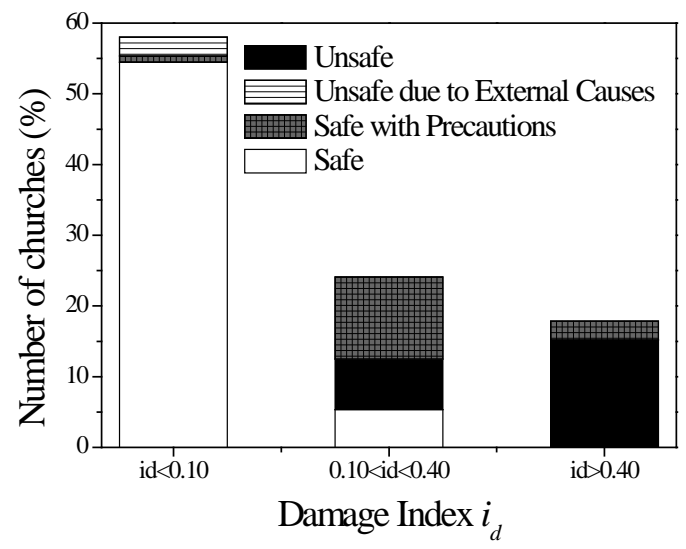

(c) correlation between the damage index $\boldsymbol{i}_{\boldsymbol{d}}$ and FFU classification

Figure 12 - Statistical correlation for all churches. 

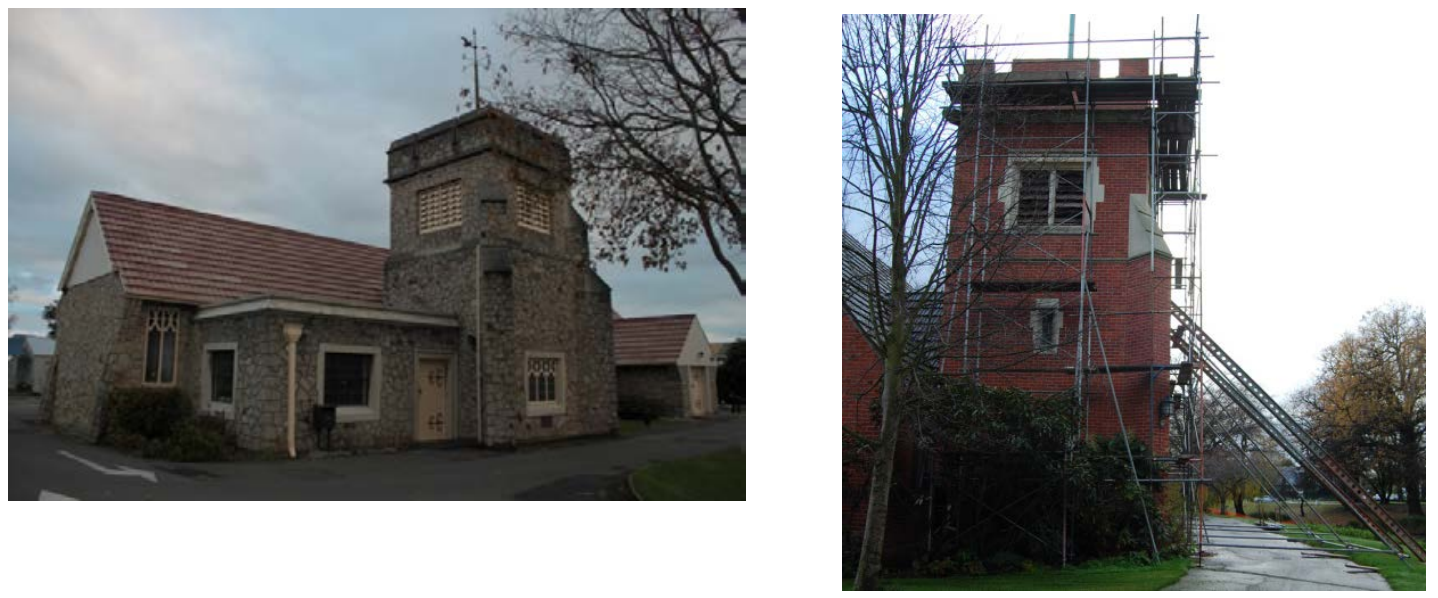

(a) green tagged (St. Martin's, stone, Middleton)

(b) yellow tagged (St. Andrew's College, brick, Papanui)

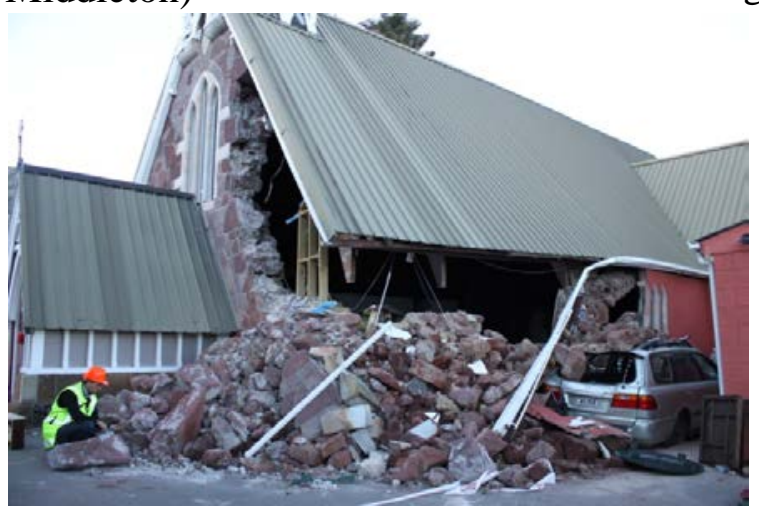

(c) red tagged (Holy Trinity, stone, Lyttleton)

Figure 13 - Examples of damaged churches. 


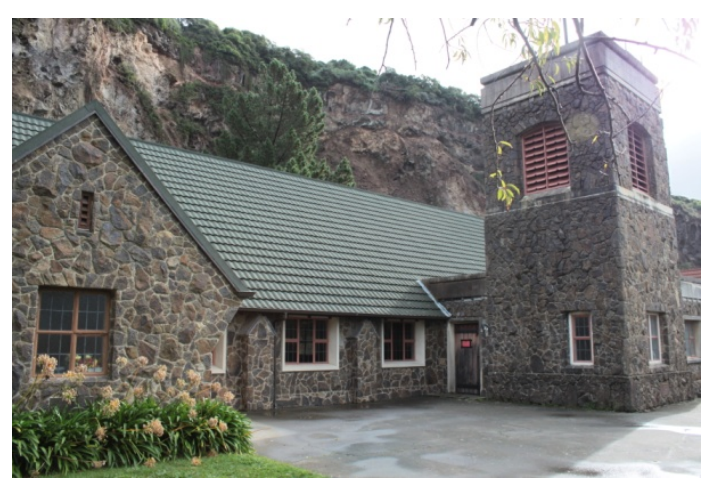

Figure 14 - Example of an undamaged church classified red due to instability of the slope shown in the background (All Saints, stone, Sumner). 


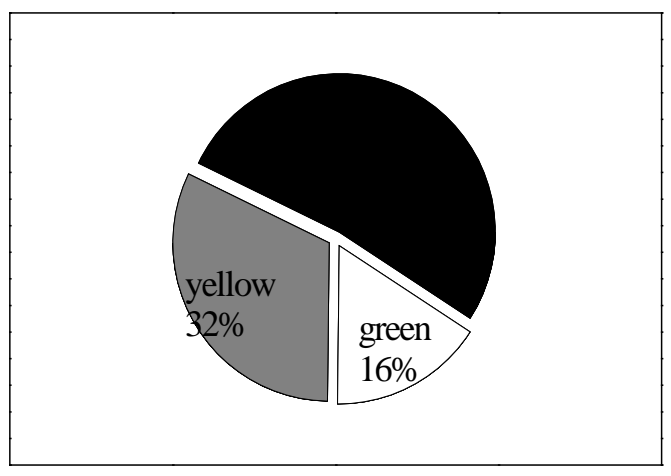

(a) placard classification

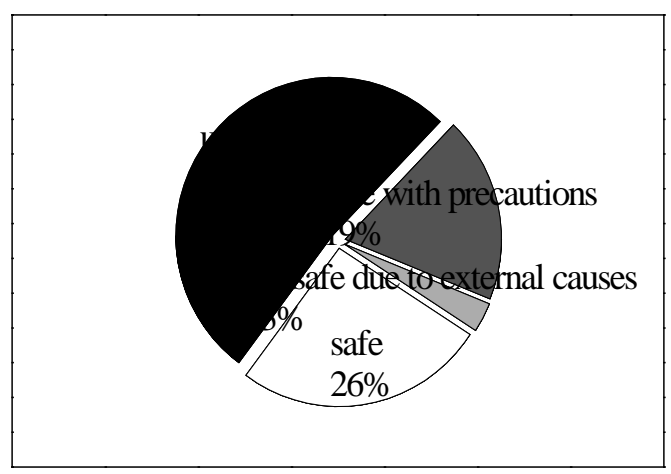

(b) FFU classification (Italian survey form [Civil Protection Department, 2006])

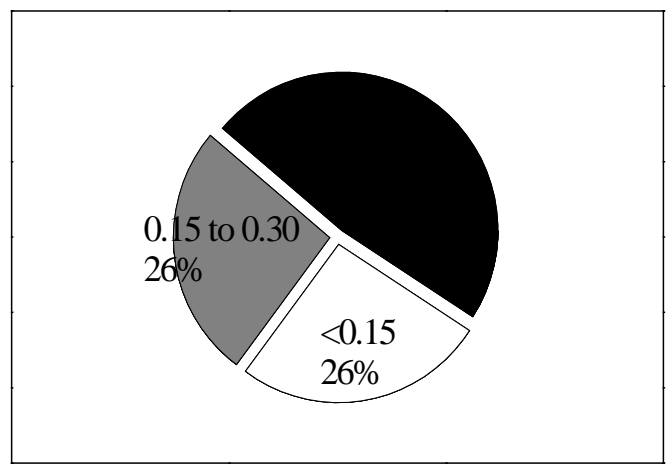

(c) damage index $\boldsymbol{i}_{\boldsymbol{d}}$ (Italian survey form [Civil Protection Department, 2006])

Figure 15 - Damage statistics for stone churches. 


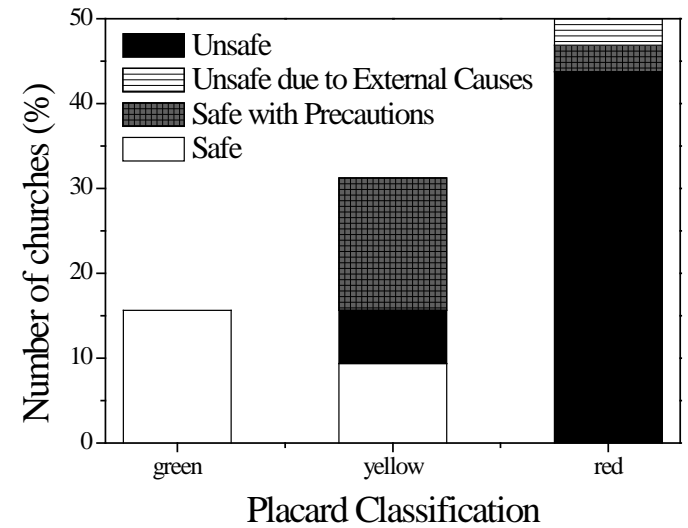

(a) correlation between the placard classification and the FFU classification

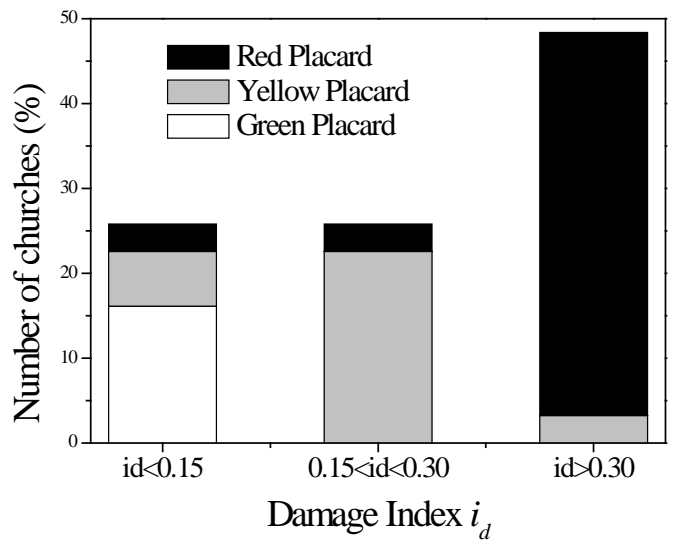

(b) correlation between the damage index $\boldsymbol{i}_{\boldsymbol{d}}$ and placard classification

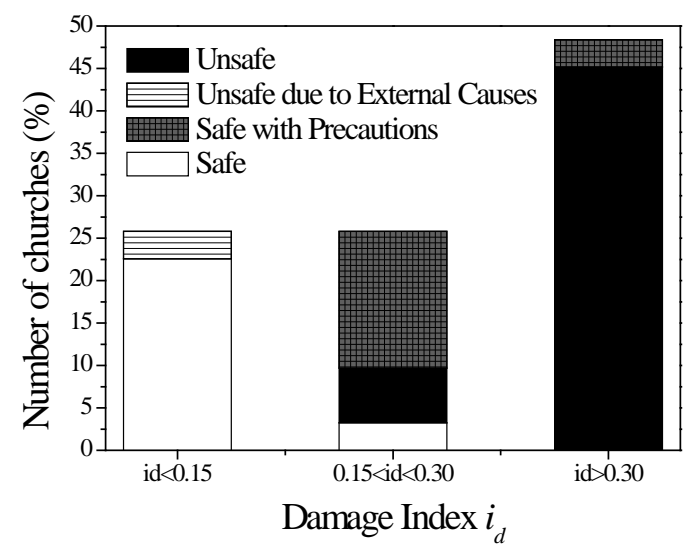

(c) correlation between the damage index $\boldsymbol{i}_{\boldsymbol{d}}$ and the FFU classification

Figure 16 - Statistical correlations for stone churches. 


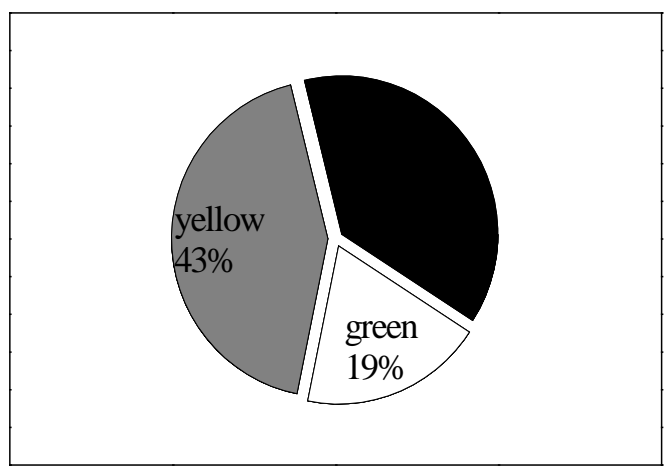

(a) placard classification

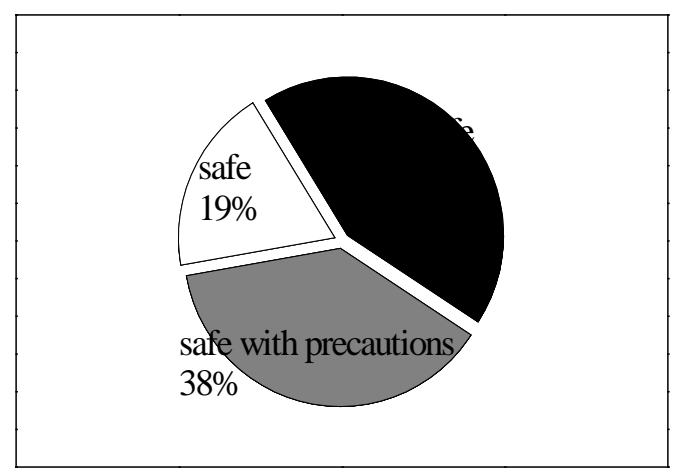

(b) FFU classification (Italian survey form [Civil Protection Department, 2006])

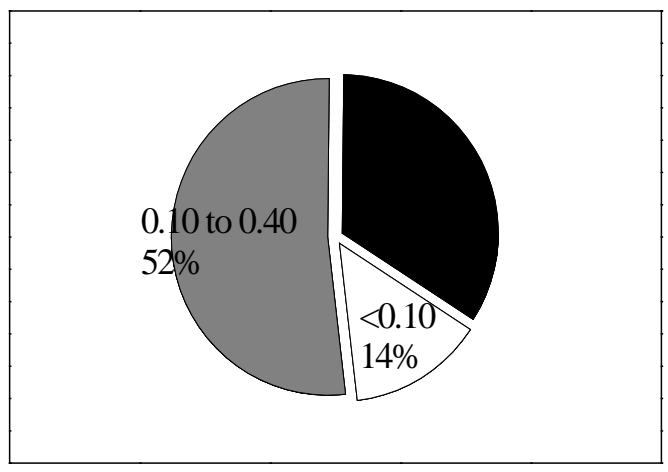

(c) damage index $\boldsymbol{i}_{\boldsymbol{d}}$ (Italian survey form [Civil Protection Department, 2006])

Figure 17 - Damage statistics for clay brick churches. 


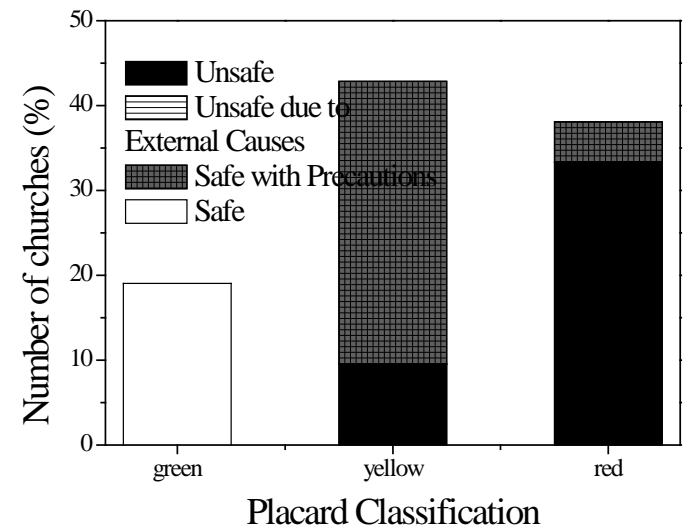

(a) correlation between the placard classification and the FFU classification

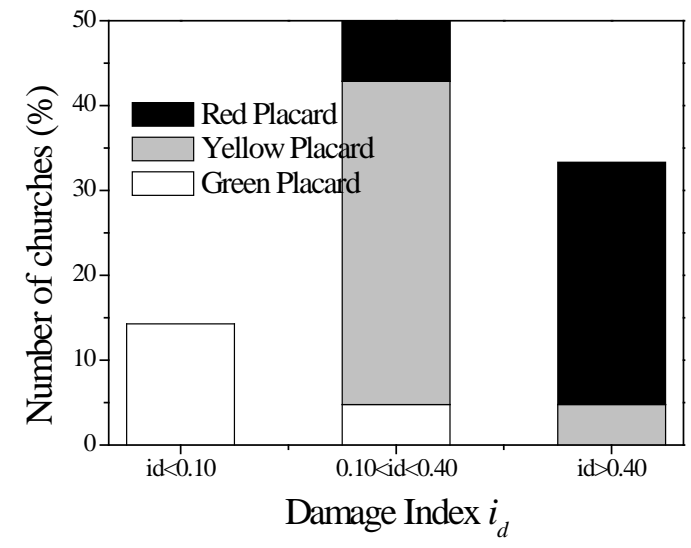

(b) correlation between the damage index $\boldsymbol{i}_{\boldsymbol{d}}$ and placard classification

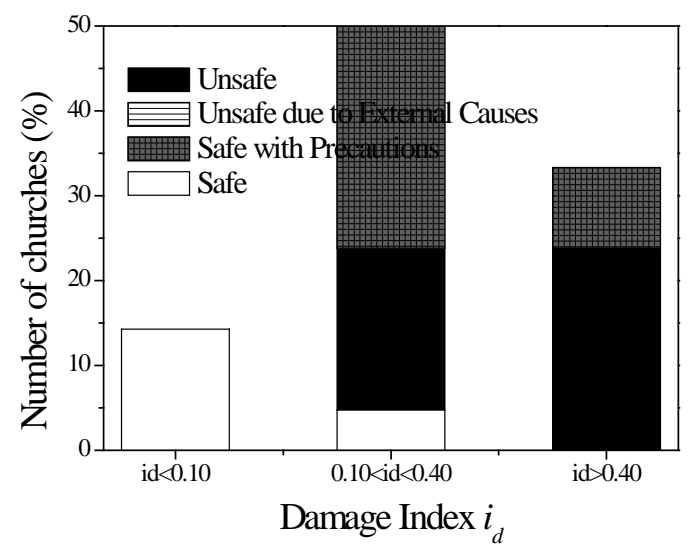

(c) correlation between the damage index $\boldsymbol{i}_{\boldsymbol{d}}$ and the FFU classification

Figure 18 - Statistical correlations for clay brick churches. 


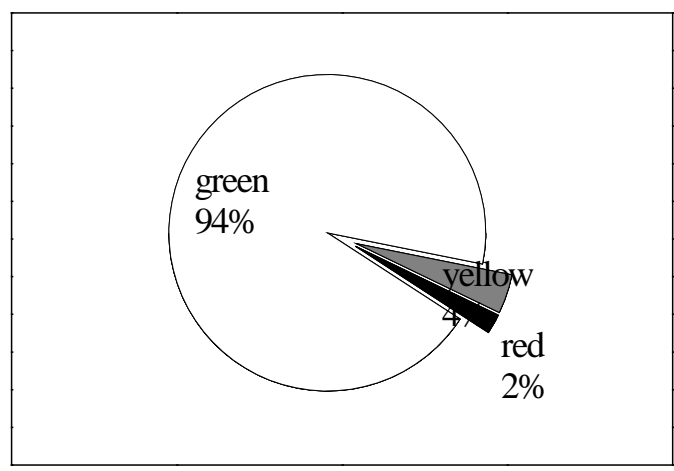

(a) placard classification

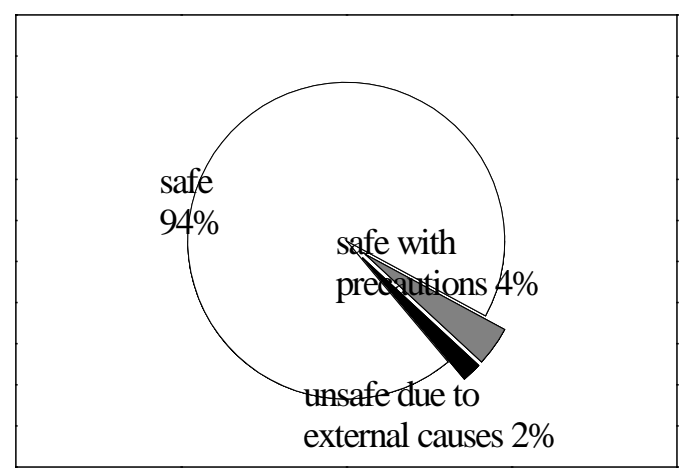

(b) FFU classification (Italian survey form)

Figure 19 - Damage statistics for timber churches. 


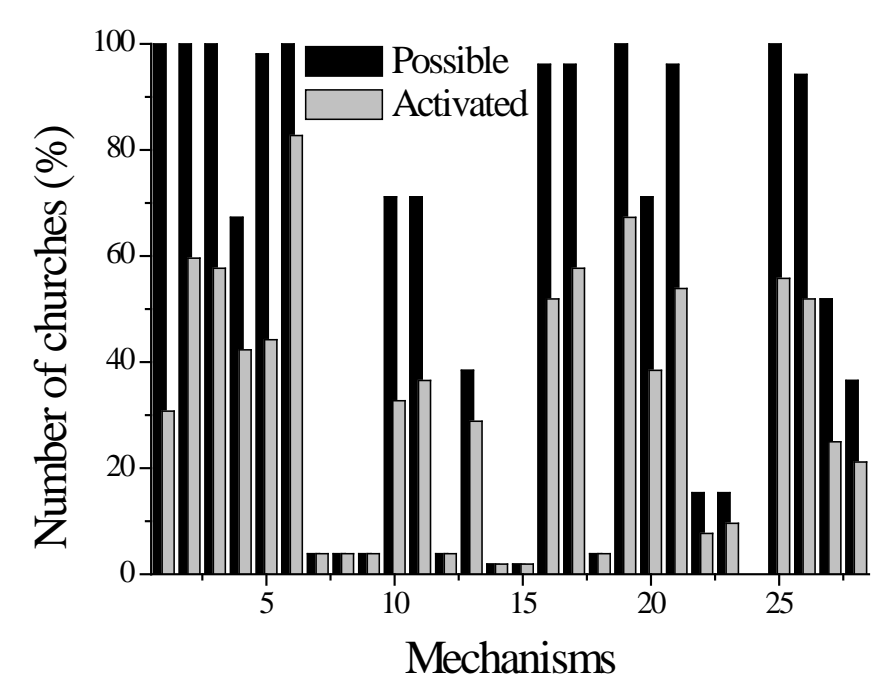

(a) possible and activated mechanisms

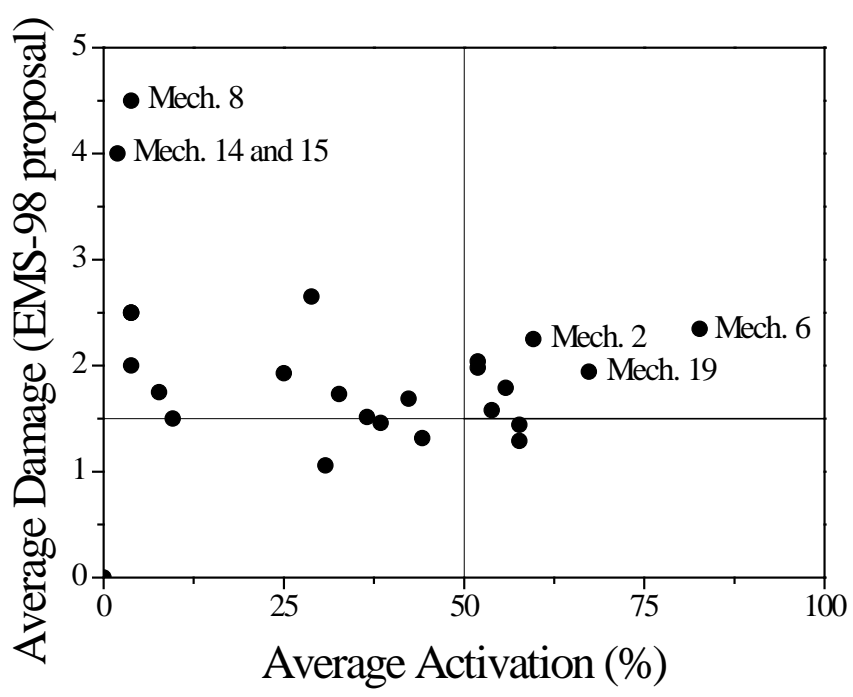

(b) Average Damage (EMS-98 proposal [Grunthal et al., 1998]) VS Average Activation (percentage of churches)

Figure 20 - Damage data for stone and clay brick churches. 


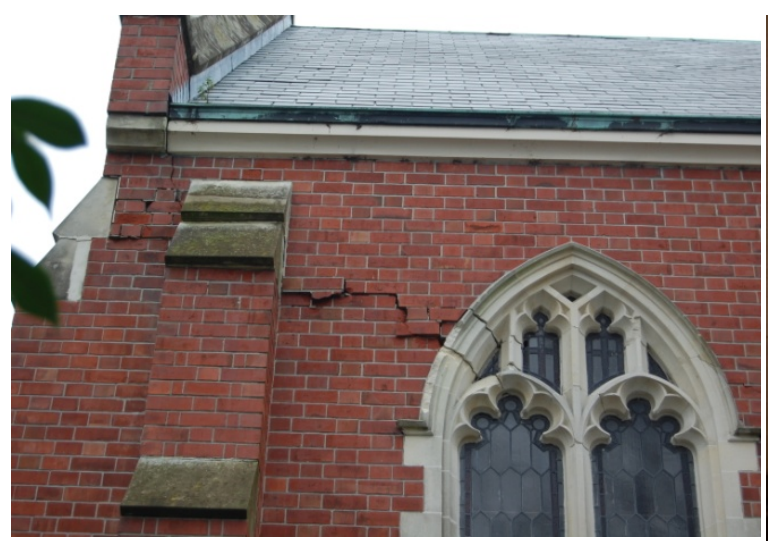

(a) shear damage in the longitudinal walls (mechanism 6), outside (Nazareth's House church, brick, Sydenham)

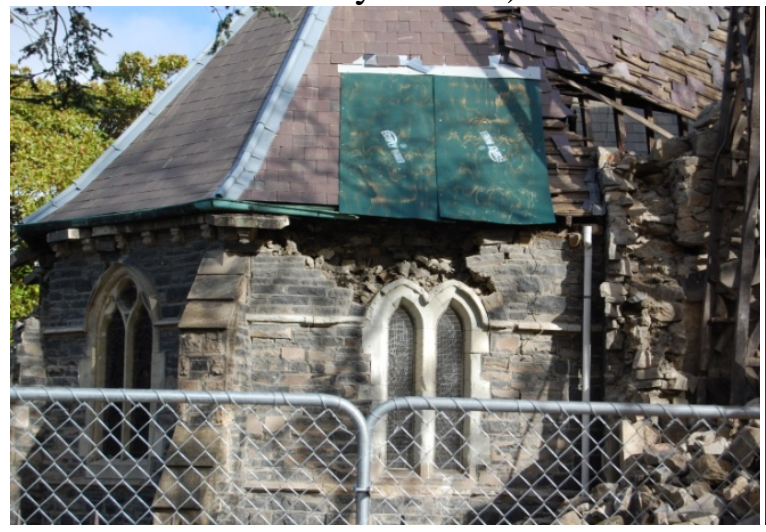

(c) hammering of the roof (mechanism 19), outside (St. John's, stone, Latimer Square)

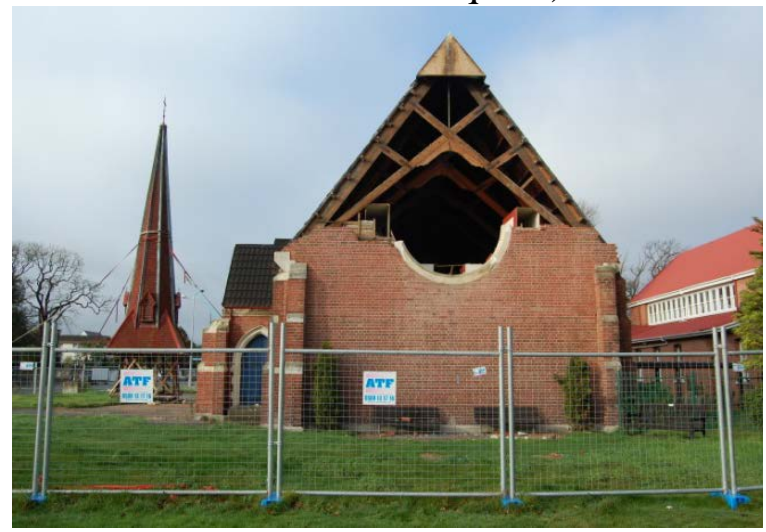

(e) overturning of the top of the facade (mechanism 2), outside (Chinese Methodist, brick, Papanui)

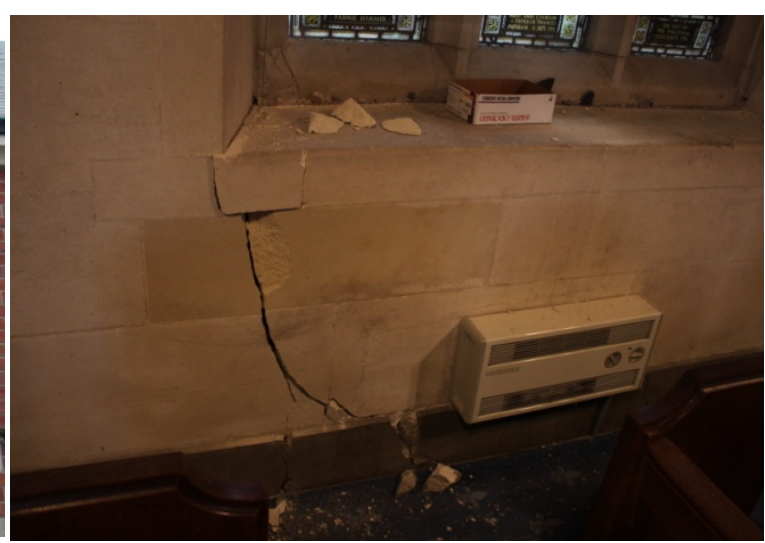

(b) shear damage in the longitudinal walls (mechanism 6), inside (St. Barnaba's, stone, Fendalton)

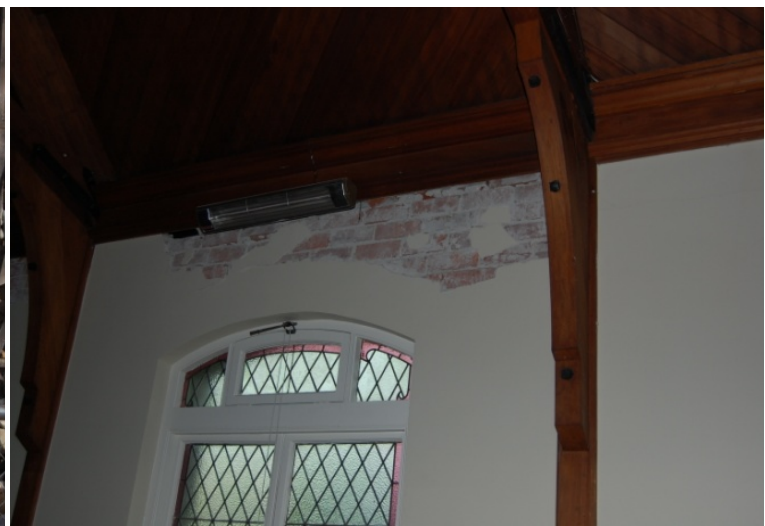

(d) hammering of the roof (mechanism 19), inside (Shirley Methodist, brick, Shirley)

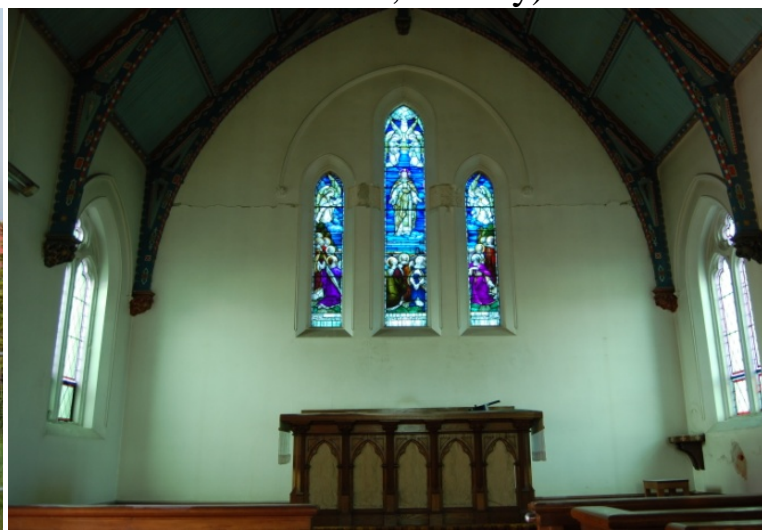

(f) overturning of the top of the facade (mechanism 2), inside (St. James, stone, Riccarton)

Figure 21 - The first, second and third most common activated mechanisms, respectively. 


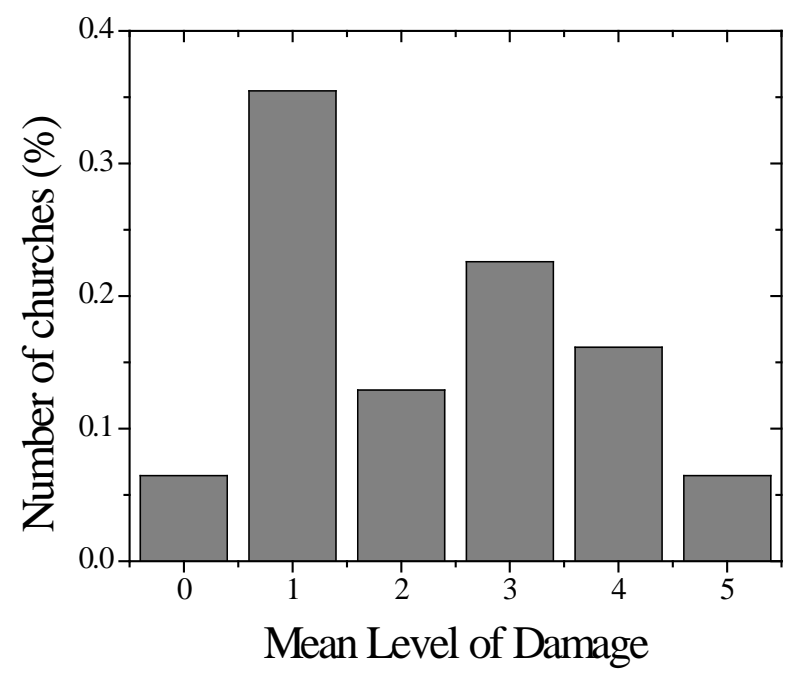

(a) stone churches

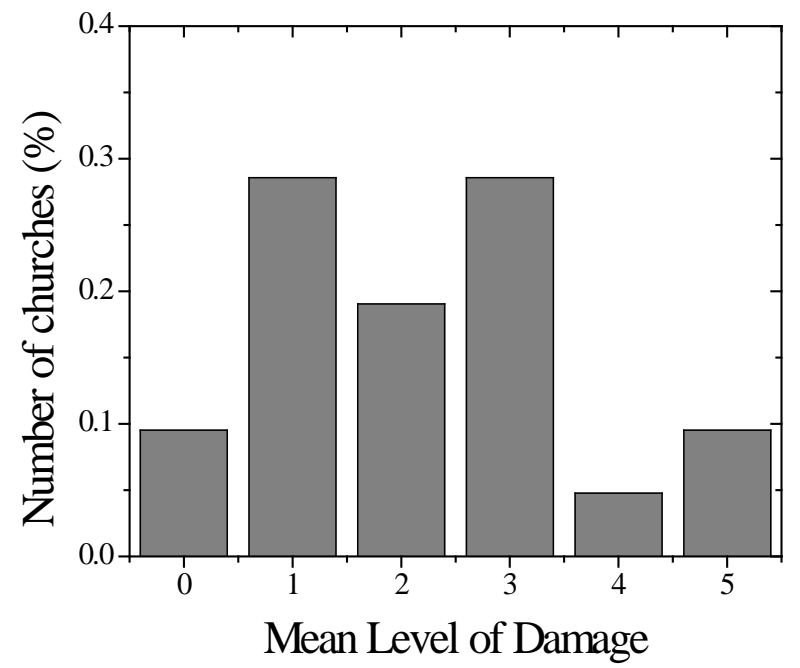

(b) clay brick churches

Figure 22 - Mean Level of Damage. 